\title{
CURRENT CONCEPTS OF EDUCATION AND DEVELOPMENT OF THERAPEUTIC EFFICACY IN POLYTRAUMA MANAGEMENT
}

$\mathrm{PhD}$ Thesis

Endre Csonka MD

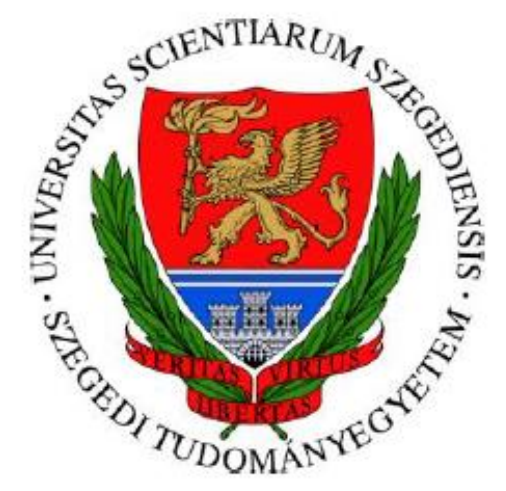

Szeged

2021 


\section{CURRENT CONCEPTS OF EDUCATION AND DEVELOPMENT OF THERAPEUTIC EFFICACY IN POLYTRAUMA MANAGEMENT}

$\mathrm{PhD}$ Thesis

Endre Csonka MD

Supervised by:

Endre Varga MD, PhD

Petra Hartmann MD, PhD

University of Szeged, Faculty of Medicine

Clinical Medical Sciences Doctoral School

PhD Program:

Clinical and Experimental Research for Reconstructive an Organ-sparing Surgery Program Director: Prof. György Lázár MD, PhD

\section{Szeged}

2021 


\section{CONTENTS}

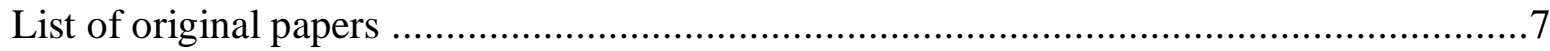

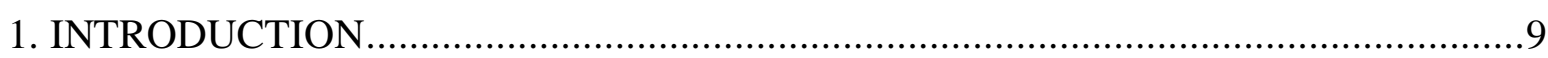

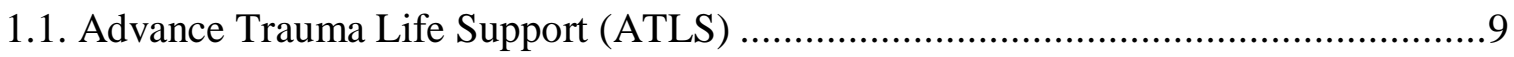

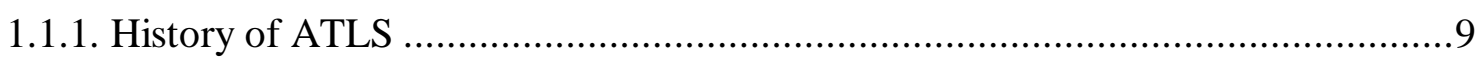

1.1.2. Dissemination ofATLS course in Hungary ………………………………....11

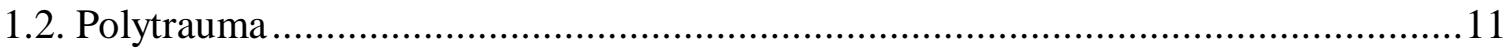

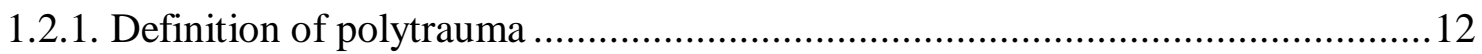

1.2.2. Initial assessment of polytrauma patient ………………...................................12

1.2.3. Current and previous classification of haemorhagic shock .................................13

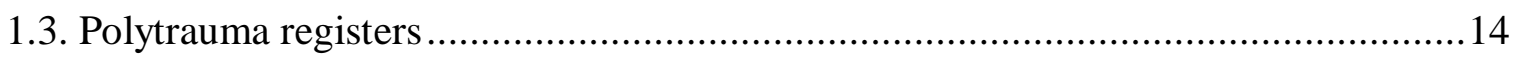

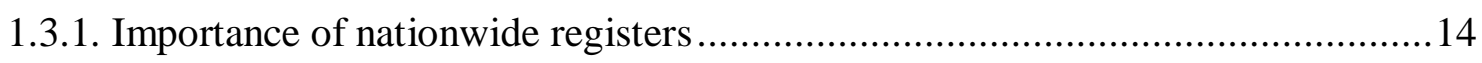

1.3.2. Need for Hungarian trauma register.................................................................15

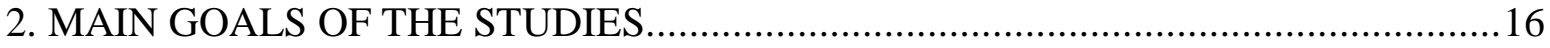

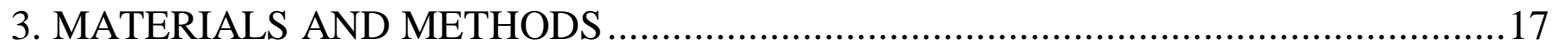

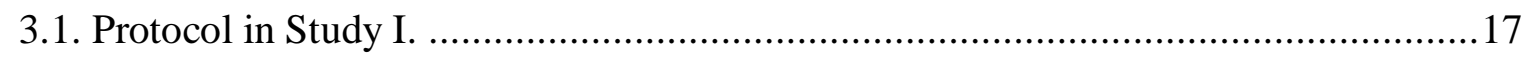

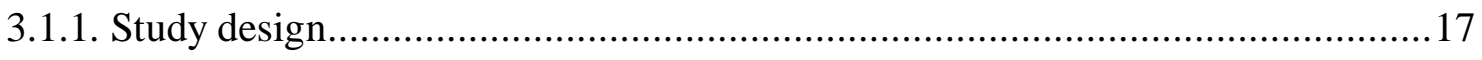

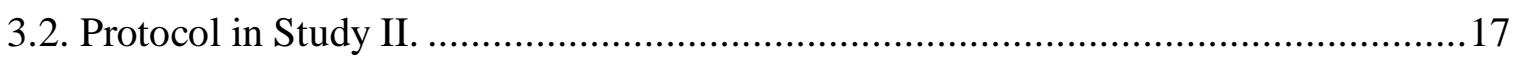

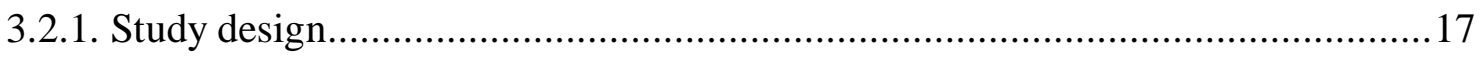

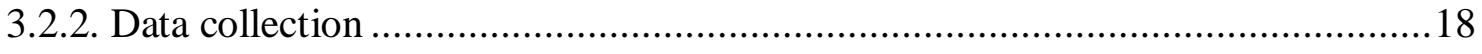

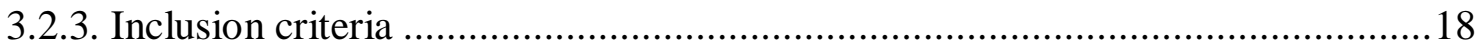

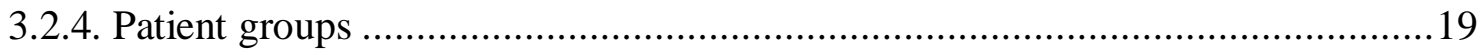

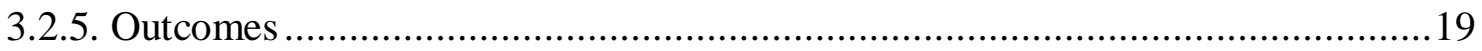

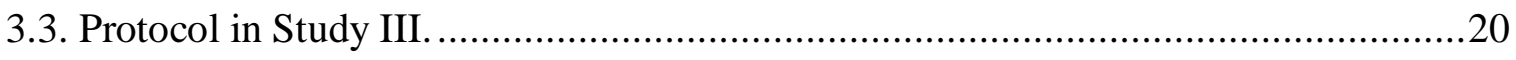

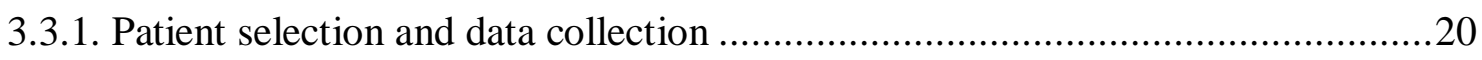

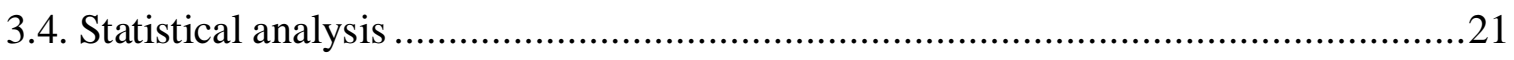

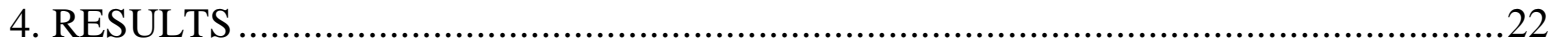

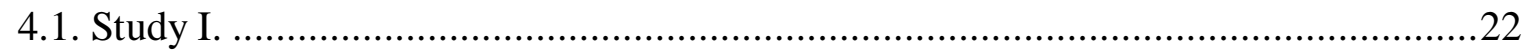

4.1.1. The results Hungarian ATLS courses …………............................................22

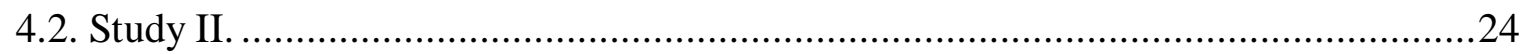

4.2.1. Patient population and demographics …………….......................................2

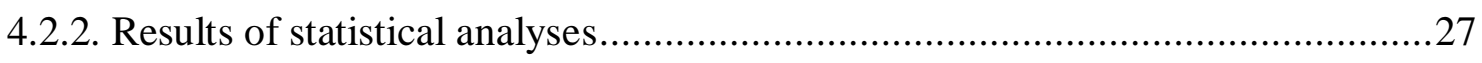

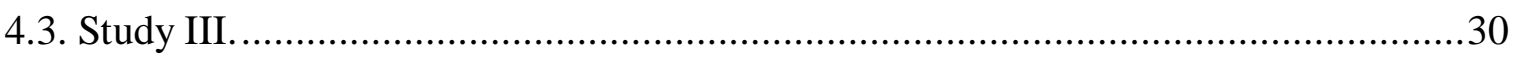




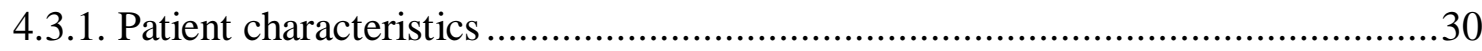

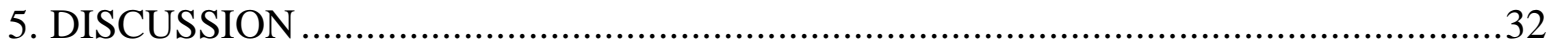

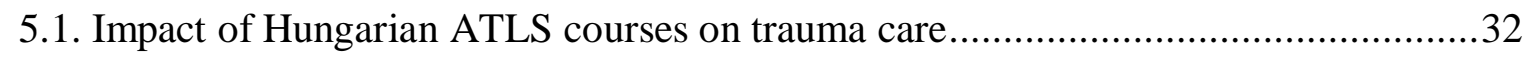

5.2. Comparison of the current and previous ATLS classifications ...............................33

5.3. Mass casualty accidenthighlighting the need for a Hungarian trauma registry ..........35

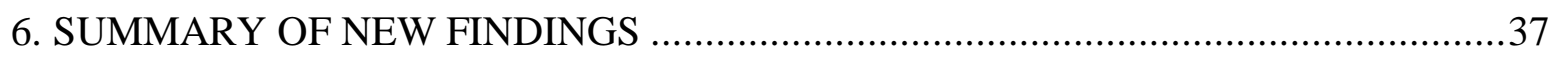

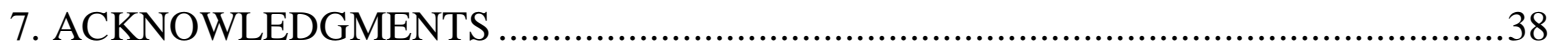

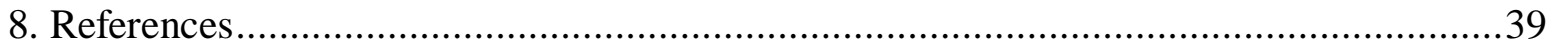

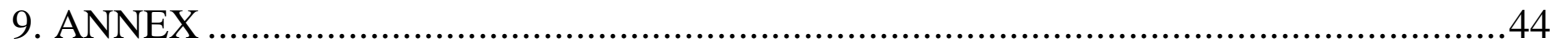


List of abbreviations

ACE Angiotensin converting enzyme

ACS American College of Surgeons

AIS Abbreviated Injury Score

ALT Alanine aminotransferase

AST Aspartate aminotransferase

ATLS Advenced Trauma Life Support

BD Base deficit

BE $\quad$ Base excess

BMI Body mass index

BPM Beats per minute

CABG Coronary Artery Bypass Grafting

CDC Centers for Disease Controll

CI Confidence Interval

CT Computer tomography

DF Degrees of freedom

DGU Deutsche Gesellschaft für Unfallchirurgie

eFAST Extended Focused Assessment with Sonography for Trauma

FAST Focused Assessment Sonography for Trauma

GCS Glasgow Coma Scale

GGT Gamma-glutamyl transferase

HR Heart rate

ICD International Statistical Classification of Diseases

ICU Intensive Care Unit

IL-1 $\quad$ Interleukin-1 $\beta$

IL-6 Interleukin-6

IL-8 Interleukin-8

IL-12 Interleukin-12

IL-18 Interleukin-18

IQR Interquartile range

ISS Injury Severity Score

MCQ Multiple Choice Question 


\begin{tabular}{ll} 
MOF & Multi organ failure \\
NISS & New Injury Severity Score \\
OR & Odds ratio \\
PLT & Platelet \\
ROC & Receiver operating characteristic \\
ROS & Reactive oxygen species \\
RTS & Revised Trauma Score \\
SBP & Systolic blood pressure \\
SD & Standard deviation \\
SIRS & Systemic Inflammatory Response Syndrome \\
SZTE & University of Szeged \\
TARN & Trauma Audit and Research Network \\
TBI & Traumatic Brain Injury \\
TLR & Toll-like receptor \\
TNF- $\alpha$ & Tumor necrosis factor- $\alpha$ \\
TRISS & Trauma Injury Severity Score \\
VS & Vital signs \\
VSTR & Victorian State Trauma Registry \\
WBC & White blood cell count \\
WHO & World Health Organization \\
\hline
\end{tabular}




\section{List of original papers}

\section{List of full papers relating to the subject of the thesis}

Varga E, Csonka E, Kószó B, Pető Z, Ágoston Z, Gyura E, Nardai G, Boa K, Süveges G. Advanced Trauma Life Support (ATLS) in Hungary; The First 10 Years.

Bull Emerg Trauma. 2016 1:48-50. IF: 0.60

Jávor P, Csonka E, Butt E, Rárosi F, Babik B, Török, Varga E, Hartmann P.

Comparison of the previous and current trauma-related shock classifications - A retrospective cohort study from a level I trauma centre.

European Surgical Research (accepted for publication)(2021). IF:2.351

Csonka E, Tuboly E, Jávor P, Varga E.

Figyelemfelhívás magyar polytrauma regiszter indítására - Egy tömegbaleset bemutatása. Magyar Traumatológia Ortopédia Kézsebészet Plasztikai sebészet (accepted for publication) (2021). IF: -

\section{List of full papers not-relating to the subject of the thesis}

Greksa F, Butt E, Csonka E, Jávor P, Tuboly E, Török L, Szabo A, Varga E, Hartmann P. Periosteal and endosteal microcirculatory injury following excessive osteosynthesis. Injury. 2021 Suppl 1:S3-S6. IF: 2.106

Horváth T, Hanák L, Hegyi P, Butt E, Solymár M, Szűcs Á, Varga O, Thien BQ, Szakács Z, Csonka E, Hartmann P. Hydroxyapatite-coated implants provide better fixation in total knee arthroplasty. A meta-analysis of randomized controlled trials.

PLoS One. 2020 15(5):e0232378. IF: 2.740

Molnár G, Csonka E, Vass A, Boros M, Kaszaki J. Circulatory consequences of reduced endogenous nitric oxide production during small-volume resuscitation. Acta Physiol Hung. 2011 4:393-408. IF: - 
Szabó A, Suki B, Csonka E, Eszlári E, Kucsa K, Vajda K, Kaszaki J, Boros M. Flow motion in the intestinal villi during hemorrhagic shock: a new method to characterize the microcirculatory changes.

Shock. 2004 (4):320-8. IF: 2.794

\section{Cumulative IF: 10.591}




\section{INTRODUCTION}

\subsection{Advance Trauma Life Support (ATLS)}

The Advanced Trauma Life Support (ATLS) course supplies its participants with a safe and effective method for the immediate treatment of severe injured patients. It gives a reliable procedure to assess a patient rapidly and accurately and resuscitate and stabilize according the priority simultaneously. Help to determine whether a patient needs exceed the resources of a facility and arrange appropriately for a patient's interhospital or intrahospital transfer. Ensure that optimal care is provided and that the level of care does not deteriorate at any point during the evaluation, resuscitation or transfer process [1].

The ATLS programs are recognized as the standard educational trauma program worldwide. The content and skills presented in this course are designed to assist doctors in providing emergency care for injured patients. The course provides the essential informations and skills for participants to identify and treat life-threatening and potencially life-treathening injuries under the extreme pressures of a fast paced procedures and athmosphere of a trauma room. Upon completing the ATLS course, the doctors will be able to establish primary and secondary survey management of acute life-threatening conditions in a timely manner. They will be able to examine a severe injured patient in apropiate order, intubate orotracheally on adult or infant patients, perform cricothyroidotomy, asses and treat a patient in shock. They will capable to make pleural decompression and insert chest tube, recognize pericardiac tamponade and treat immediately, use of peritoneal lavage and make Focused Assessment with Sonography for Trauma (FAST) examination. The will susceptible to evaluate and treat a patient with brain injury including use of Glasgow Coma Scale (GCS), recognize musculoskeletal injuries and manage them, protect the spinal cord during the whole process and make the radiologic and clinical evaluation of spine injuries. Analyzing the datas from World Health Organization (WHO) and the Centers for Disease Controll (CDC) the burden of injury is even more significant, accounting for $18 \%$ of the world's total diseases. The collected data suggest that ATLS has a positive impact on the value of trauma care.

\subsubsection{History of ATLS}

Advanced Trauma Life Support (ATLS) programs are recognized as the standard educational trauma program worldwide. Data suggest that ATLS has a positive impact on 
the value of trauma care. The ATLS Hungary program has been started in 2005, celebrating its 10-year anniversary this year (in 2015). In the present brief communication a brief overview is provided on the program. Student evaluation and statistical data about the participants were collected throughout the 10-year history of the Hungarian program. Student evaluation shows a high level of satisfaction amongst the participating doctors. Most participants are working in higher level centers. The Hungarian program shows good quality according to the participants. Establishing at least one new center is crucial to be able to provide the course for every professional interested in it or required to take it.

The history of ATLS is well known to have started with the famous "Nebraska Experience" of an orthopedic surgeon, Dr. James Styner's involvement in a tragic family plane crash in rural Nebraska in 1976. Dr. Styner's patient experience of inadequate and inconsistent trauma care has facilitated the development of an educational program concerning trauma care in 1978, having been quickly accepted by the American College of Surgeons (ACS) [2]. The following decades brought a wonderful dissemination of the idea across the globe, as ATLS has been taught in 63 countries worldwide as of 2012 [2]. The intensive ATLS course includes the teaching of systematic approach to trauma care by means of simulated scenarios, practical skills teaching, lectures, and discussions, assessment including both skills examination and MCQ testing. The student course manual is being revised every 4 years to keep the material up-to-date. The advantages of having a systematic approach to trauma seem straightforward, however, it is quite hard to measure the impact of it on the quality of care. Mohammad et al. have performed a systematic review of the available literature about the impact of ATLS both educationally and in terms of quality of care. They have concluded that there is strong evidence supporting the educational aspects of the positive impact of ATLS, however, its effect on mortality needs to be further investigated [3]. The 2014 update of the publication of the Cochrane Database of Systematic Reviews, concerning the same topic have had a similar conclusion. They have also stated that highquality, controlled investigation of the systemic effect of ATLS is very challenging [4]. However, there are some good quality investigations in the topic. Hashmi et al. have found that patients were 4.9 times less likely to die and 2.6 times less likely to have complications after the implementation of an ATLS-based trauma system, compared to the period before [5]. Hedges et al. have investigated the effect of certain ATLS-based interventions on survival of high-risk patients in a rural hospital. They have found that ATLS-based administration of blood products and patient transfer to a higher level center improved 
survival, underlining the positive impact of ATLS on quality of care [6]. Medical staff undergone ATLS training have also been shown to be more effective in simulated trauma scenarios by Williams et al., [7].

\subsubsection{Dissemination of ATLS course in Hungary}

The history of ATLS in Hungary started in 1993 with the first author of this present article having the chance to see the concept in work in Canada. This experience led to the establishment of a workgroup of four Hungarian trauma surgeons at the University of Szeged (Zsolt Balogh, János Tomka, Gábor Süveges, and Endre Varga being involved). This was followed by years of hard work to make it possible to start the Hungarian ATLS program. The ACS agreed on starting the Hungarian program in 1999, and after establishing the financial and infrastructural background, the first course was held in Szeged in 2005, just a couple of years later than the first German one. A big strength of our course is the opportunity to perform procedures in the state-of-the-art animal lab of the University of Szeged. ATLS Hungary was also a founding member of ATLS Europe and is an active member of it ever since.

In Hungary, we held the 20th ATLS course in 2015, and to date, a total of 39 courses have been organized and completed by more than 600 physicians. In 2016, we launched the second course venue in Budapest. It is of high importance that the completion of ATLS course is mandatory in the orthopedics and trauma specialization and recommended for resident doctors in anaesthesiology and intensive therapy, and emergency medicine.

\subsection{Polytrauma}

Severe trauma is one of leading causes of death among the younger generations $[8,9]$. The survivors of the first 24 hours are at high risk for inflammation related complications such as severe systemic inflammatory response syndrome (SIRS), organ dysfunctions, sepsis and postoperative complications [10,11]. The treatment of major trauma patients is costintensive also. The length of the average intensive care unit stay for survivors with an Injury Severity Score (ISS) $\geq 16$ is two weeks, and in most cases, an extended rehabilitation phase is also required [12]. Despite these facts, treatment strategies are still often based on expert opinions instead of clear guidelines determined by higher levels of evidence. 


\subsubsection{Definition of polytrauma}

The term "polytrauma" has been frequently defined in terms of a high Injury Severity Score (ISS) and has been generally used interchangeably with terms such as "severely injured" or "multiple trauma" [13]. The internationally accepted threshold of an ISS $\geq 16$ is based on the description as being predictive of a mortality risk above $10 \%$ [14]. However, a number of definitions for polytrauma with various ISS values (ISS > 15 [15], ISS > 16 [16], ISS > 18 [17], ISS $\geq 18$ [18], or ISS > 25 [19] have been described in the literature.

Polytrauma patients are expected to have a high risk of mortality than that obtained by the summation of expected mortality owing to their individual injuries. The expression was defined using the new Berlin definition, as cases with an Abbreviated Injury Scale (AIS) $\geq$ 3 for two or more different body regions and one or more additional variables from five physiologic parameters. These parameters are hypotension [systolic blood pressure $\leq 90$ $\mathrm{mmHg}$ ], unconsciousness [Glasgow Coma Scale score $\leq 8$ ], acidosis [base excess $\leq-6.0$ ], coagulopathy [partial thromboplastin time $\geq 40 \mathrm{~s}$ or international normalized ratio $\geq 1.4$ ], and age $[\geq 70$ years $][20]$.

\subsubsection{Initial assessment of polytrauma patient}

When treating injured patients, clinicians rapidly assess injuries and perform life-preserving therapy. Because timing is crucial, a systematic approach that can be rapidly and accurately applied is essential. This approach called "initial assessment" consists of primary and secondary survey. During primary survey, the doctors have to recognize all of the life threatening injuries of the patient and stabilize vital functions, including invasive methods if needed. Recommended sequence $\mathrm{ABCDE}$ helps to treat life threatening injuries in proper order: "treat first wich kills first". The letter "A" means airway maintenance with restriction of cervical spine motion, "B" stands for breathing and ventilation function, "C" refers to circulatory system problems and " $D$ " means disability, neurologic evaluation and $\mathrm{E}$ is exposure and environmental control.

The early recognition of shock is essential in trauma patients. Diagnosing shock in trauma patients relies on a synthesis of clinical findings and laboratory tests. No single vital sign and no laboratory test can definitively diagnose shock on its own. The first step to recognize its presence, the second step is managing shock and identify the probable cause of shock simultaneously. Hemorrhage is the most common cause of shock after injury and all patients with multiple injuries have some degree of hypovolemia. Most injured patients in shock have hypovolemia, but they may suffer from cardiogenic, obstructive, neurogenic, 12 
and rarely septic shock. It is important to note that hemorrhage resulting in hypovolemic shock is the predominant cause of preventable deaths after injury. Identifying, controlling blood loss and initiating resuscitation are therefore crucial steps in assessing and managing such patients. Early circulatory responses to blood loss are compensatory vasoconstriction of cutaneous, muscular and visceral circulation to preserve blood flow to heart, brain and kidneys. The usual response to acute circulatory volume depletion is an increase in heart rate to preserve cardiac output. In most cases tachycardia is the earliest sign of shock. The release of endogenous catecholamines increases peripheral vascular resistency, wich increases diastolic blood pressure and reduces pulse pressure, however this increase in pressure will not increase organ perfusion and tissue oxygenation significantly. Therefore, early detection of shock is essential for adequate patient care and the necessary life-saving interventions.

\subsubsection{Current and previous classification of haemorhagic shock}

Injuries accompanied by massive blood loss are leading cause of death among young adults $[21,22]$. Hypovolemic shock is the second main cause of mortality in trauma patients $[23,24]$, and the outcome can be improved significantly through early recognition, intravenous fluid resuscitation and blood transfusions [25]. Currently, the Advanced Trauma Life Support (ATLS) program provides well-established guidances for early assessment and initial management of major trauma and suspected hemorrhage by allocating the patients into severity classes I-IV, respectively [26,27]. Until recently, the earlier guidance proposed the use of vital signs (VS) only, including heart rate (HR), systolic blood pressure (SBP) and Glasgow Coma Scale (GCS) to aid the recognition of shock and estimate blood loss [28,29]. However, the predictive value of VS-based classification has been questioned and in 2013, the analysis of the Trauma Register DGU® (Deutsche Gesellschaft für Unfallchirurgie) indicated that the VS-based classification does not reflect the clinical condition accurately. Therefore, the use of base deficit (BD) as a sole parameter in the classification has been recommended [30,31].

$\mathrm{BD}$ is a metabolic marker reflecting the acid-base status of the patients and commonly used to assess hemorrhage and its consequences [32-34]. Several studies have documented its ability to predict mortality and post-injury transfusion requirements and highlighted its role in the early assessment of condition in trauma patients [30, 35-39]. Therefore, the latest ATLS recommendation expanded the assessment criteria with the BD value [26]. However, the specificity of $\mathrm{BD}$ for hypovolemia prediction is still questionable, since not only 13 
metabolic acidosis, but other factors such crystalloids (lactated Ringer or saline) can also elevate BD [38]. Furthermore, alcohol or drugs, commonly seen in trauma patients, may also diminish its predictive accuracy [40,41]. Besides, it has been demonstrated that patients over 55 years may have significant injuries and mortality risk without manifest BD alterations [42].

\subsection{Polytrauma registers}

\subsubsection{Importance of nationwide registers}

Nowadays, modern medical protocols are based on evidence-based knowledge, and guidelines based solely on expert opinion are increasingly being pushed into the background. Recently, due to registry and large cohort analyzes, important paradigm shifts have taken place in the management strategies of the severely injured $[28,31,43]$. Nonetheless, the mortality rate of severe trauma is still high [44] and there are still several controversial issues in this field $[45,46]$. According to the experience from the recent past, well-functioning registries can play a key role in the further development of emergency trauma protocols [47]. Two studies of Mutschler et al. in 2013 and 2014 [28,30] are good examples how international trauma registries (Trauma Register DGU (Deutsche Gesellschaft für Unfallchirurgie), TARN (Trauma Audit and Research Network) change trauma protocols. The result indicated that the vital sign based classification does not reflect clinical reality accurately. Consequently, the assessment criteria were extended with the Base Deficit (BD).

Medical registries are prospective and systematic collections of clinical, demographic, and other data from patients who meet specific criteria, for pre-defined purposes $[11,47,48]$. Large amounts of clinical and demographic data may be suitable for setting up and validating hypotheses, to design protocols and control their effectiveness, quality control of patient care, to compare the performance of institutions, regions, or countries; to select participants for clinical trials, for prevention purposes or even for the analysis of prehospital and rehabilitation phases $[27,45,49]$. The positive impact of trauma registers on the quality of patient care and scientific activity seems to be evident [12]. This is especially true for the treatment of severe injuries (Injury Severity Score (ISS) $\geq 16$ ), where randomized controlled trials are hard to conduct due to the time factor, the unconscious state of many patients, and the interdisciplinary nature of patient management [44]. The Victorian State Trauma Registry (VSTR) in Australia illustrates well that monitoring patient care via 
statistics makes it possible to identify systemic problems, thereby provides an opportunity for quality improvement. VSTR's 2-year statistics (2001-2003) showed that one in five injured transport times in the region that did not require a technical rescue exceeded 1 hour; in $60 \%$ of individuals with hemodynamically unstable, penetrating trauma, ambulance staff spent more than 10 minutes on site, $48.4 \%$ of severe injuries with GCS $<9$ mental status did not undergo intubation at the site.In $28.7 \%$ of major trauma cases, no complete trauma team alert occurred; furthermore, in $23.7 \%$ of head injuries, more than 2 hours elapsed before performing a cranial CT from hospital arrival [12].

\subsubsection{Need for Hungarian trauma register}

In recognition of this, the concept of a united European trauma registry has already been born [50]. High-quality polytrauma care is provided in the level I trauma centers of Hungary and Advanced Trauma Life Support courses have been organized for 15 years, however national registry in Hungary does not exists.

In the 5 level I trauma centres of Hungary, the priorities of emergency trauma care correspond to ATLS principles. Moreover, the country is a founding member of ATLS Europe and organizes courses since 15 years [27]. Despite of the good quality of care, Hungary has no trauma registry, consequently, a significant amount of scientific information becomes wasted.

Registers can usually focus only on a limited number of issues, as if the administrative burden of the amount of data to be recorded depletes the available resources, the database will be unsustainable. Consequently, it is crucial to set realistic goalsfor a registry [47]. If the data collection works well in the initial phase, the list of objectives and thus the parameters to be documented can be expanded later. Patients in the registry are selected based on predefined inclusion criteria. Many trauma registries collect data only from severely injured people, for whom it is obvious to use a severity assessment scale, usually Injury Severity Score (ISS), Revised Trauma Score (RTS), New Injury Severity Score (NISS), or Trauma Injury Severity Score (TRISS). The use of severity scales is complicated by the fact that it is not possible to accurately assess lesions immediately upon patient arrival. After primary survey and stabilization, further imaging is often required to establish the complete list of diagnoses [51]. As a result, some countries use a more practical, more measurable set of criteria for selecting severely injured people. Since 2013, the German Trauma Register DGU® only includes trauma patients with a need for intensive care. This selection limits administrative burdens, but includes care-critical patients, optimizing the cost-benefit ratio of operating a database [52]. 


\section{MAIN GOALS OF THE STUDIES}

Our main goal is to analyze different aspects of education and data collection that could lead to the quality development of trauma care in Hungary. The approach provided by ATLS has become a relevant part of education in the field of trauma worldwide, since it is associated with the decrease in the number of preventable deaths. We aim to emphasize the importance of organizing courses and actively search for new areas of improvement in ATLS. We also aim to highlight the need for a national trauma register, as unified systematic data collection could lead to better quality control, identification of new predictive parameters, and ultimately better patient care.

- As a first step, in study I., we have provided a brief overview on the ATLS program. Student evaluation and statistical data about the participants were collected throughout the 10-year history of the Hungarian program.

- Then, we set out to examine the predictive power of the currently accepted ATLS classification of hypovolemic shock to confirm or refute the superiority of VS+BD detection over the previously used (VS only) protocol. Thereforein study II.we have conducted a retrospective cohort analysis at a level I trauma centre to compare the VS+BD and VS classifications in terms of their ability to predict mortality. Our secondary goal was to determine the parameters with strong prognostic possibilities in the early assessment phases of the injured. Therefore, the predictive values of HR, SBP, GCS and BD were also calculated.

- Finally, we aimed to highlight the need for a national registry in our country via presenting one mass casualty. In search for new predictive factors, markers of shock and routine labor parameters were collected and analyzed. We aim to demonstrate that isolated cases can draw attention to new contexts and point out new areas of improvement; however, in the lack of possibilities for validation, new ideas cannot become a part of evidence-based medicine. In order to overcome our limitations, the establishment of a national trauma registry is required urgently. 


\section{MATERIALS AND METHODS}

The clinical studies were conducted in accordance with the Declaration of Helsinki and has been approved by the local medical ethics committee at the University of Szeged under reference number 182/2019-SZTE.

\subsection{Protocol in Study $I$.}

\subsubsection{Study design}

The objective of this study is to provide a narrative analysis to explore the association of ATLS courses and participants satisfaction in regards to educational strategy, quality of lectures and skills practices and possible effectiveness and efficiency of the course on trauma care. Secondary data analysis was completed on survey responses from 305 participants of the first 20 Hungarian ATLS courses.

This retrospective study used a secondary data source from the ATLS feedback questionnaires. The survey contained questions that asked participants to identify the level of trauma care center they came from and their speciality fields. Additional survey items asking participants to rate office staff were removed from the analysis, leaving 16 survey items that were retained for the purpose of the study. Five items were grouped to the category of educational strategy and possible future usefulness. Survey items used a variety of categorical measures including yes/no, never/sometimes/usually/always, and not at all/a little/some/a lot. Five items into the category of lectures and six items were grouped into the category of skills practices and simulated scenarios. The overall lectures and skills practices rating survey item used a Likert-type scale of 1 to $5(1=$ worst lecture possible; $5=$ best lecture possible) in whole number increments.

\subsection{Protocol in Study II.}

\subsubsection{Study design}

The present study is a retrospective cohort analysis at a single, level I trauma centre located in an urban area. The level I qualification is based on national standards regarding the kinds of resources available and the number of patients admitted yearly. The designation criteria correspond to United States of America standards. 


\subsubsection{Data collection}

In the past decades, there were several important changes in emergency trauma guidelines, such as the paradigm shift in fluid resuscitation and the introduction of tranexamic acid $[53,54]$. Taking this into account, we decided to analyze data only from the past 5 years, the data were collected between 11 July 2014 and 11 September 2019 from the electronic database (MedSolution) at the University of Szeged. The protocols of emergency trauma care including massive transfusion protocols at the institution have been in complience with the principles of ATLS during the whole study period.

\subsubsection{Inclusion criteria}

The inclusion criteria consisted of trauma team activation, transport directly from scene, age of 16 years or greater, a detailed documentation including Abbreviated Injury Scale (AIS), Injury Severity Score (ISS), the accurate mechanism of injury and a complete dataset for HR, SBP, GCS and BD recorded at presentation. The activation of the trauma team is based on anatomical and physiological criteria and the mechanism of injury. High-energy trauma is characterized by high amount of kinetic energy inducing severe tissue damage; and typically sustained by road traffic accidents, crush or blust injuries, and falling from heights. The clinical handover between paramedics and emergency department staff follows the MIST and AMPLE templates (MIST: M - Mechanism of Injury; I - Injuries Sustained; $\mathrm{S}$ - Signs; T - Treatment and Trends in the Vital Signs. AMPLE: A - Allergies; M Medications; P - Past Medical History; L - Last Ate; E - Events). The age limit of 16 years was selected according to the fact that normal values of HR and SBP by adolescents above that age do not differ largely from the normal values by adults $[55,56]$. The recorded variables included the mechanism of injury, the International Statistical Classification of Diseases and Related Health Problems (ICD) codes, vital parameters (HR, SBP and GCS) measured by the trauma team at presentation, BD and 30-day survival. Although prehospital treatment might have influenced the parameters, paramedics use a unified protocol including guidance regarding the prehospital fluid resuscitation, administration of vasopressors and opioid analgesics also. When patients were discharged from the hospital earlier than 30 days, the follow-up was completed as a part of outpatient care.

Patients who received cardiopulmonal resuscitation on scene or primary survey in another institute were excluded. Additionally, imprecise documentation and missing variables also entailed exclusion. 


\subsubsection{Patient groups}

The ATLS does not explicitly declare whether the worst parameter or a combination of all the parameters should determine the severity class of the patient. Most trauma patients cannot be allocated correctly to the four ATLS severity classes (I-IV) when a combination of vital parameters is assessed [28,30]. Therefore, the participant's allocation was based on their worst parameter within the VS and VS+BD criteria. Since the current ATLS shock classification does not describe exact values for HR, SBP and GCS, we adopted HR values from the previous ATLS classification and SBP and GCS values from the study of Dunham et al. to make the criteria objective and transparent [39]. (Table 1)

\begin{tabular}{|c|c|c|c|c|c|c|}
\hline \multicolumn{3}{|c|}{$\begin{array}{l}\text { Severity classes } \\
\text { Estimated blood loss }\end{array}$} & $\begin{array}{l}\text { Class I } \\
<15 \%\end{array}$ & $\begin{array}{l}\text { Class II } \\
15-30 \%\end{array}$ & $\begin{array}{l}\text { Class III } \\
31-40 \%\end{array}$ & $\begin{array}{c}\text { Class IV } \\
>40 \%\end{array}$ \\
\hline \multirow{4}{*}{$\begin{array}{l}\frac{4}{5} \\
\frac{0}{0} \\
\frac{0}{0} \\
\frac{0}{2} \\
\frac{1}{2}\end{array}$} & \multirow{3}{*}{$s$} & $\mathrm{HR}^{*}$ (bpm) & $<100$ & $100-119$ & $120-139$ & $\geq 140$ \\
\hline & & $\mathrm{SBP}^{*}(\mathrm{mmHg})$ & $\geq 110$ & $100-109$ & $90-99$ & $<90$ \\
\hline & & GCS* & 15 & 15 & $12-14$ & $<12$ \\
\hline & \multicolumn{2}{|c|}{$\mathrm{BD}^{* *}(\mathrm{mEq} / \mathrm{L})$} & $0-2 \mathrm{mEq}$ & $2-6 \mathrm{mEq}$ & 6-10 mEq & $\geq 10 \mathrm{mEq}$ \\
\hline \multicolumn{3}{|c|}{ Transfusion } & Monitor & Possible & Yes & Massive transfusion \\
\hline
\end{tabular}

Table 1.Simplified shock classification using absolute values. The table is based on the recommendations of ATLS [6]. Pulse pressure, respiratory rate and urinary output are not included in the physiologic variables. Instead of trends, absolute values were used to make the criteria more objective. $\mathrm{VS}=$ vital sign, $\mathrm{HR}=$ heart rate, $\mathrm{SBP}=$ systolic blood pressure, GCS=Glasgow Coma Scale, $\mathrm{BD}=$ base deficit, bpm=beats per minute

*The current ATLS classification for hypovolemic shock only offers exact values for BD. The values for HR were adopted from the previous (9th) ATLS shock classification. For SBP and GCS, we adopted the values used by Dunham et al. [39].

**A negative base excess (BE) is called base deficit (BD) and indicates metabolic acidosis

\subsubsection{Outcomes}

As a primary outcome, we compared the VS and VS+BD classifications with respect to 30day mortality, taking the close relationship of the severity of bleeding to the risk for adverse outcomes into consideration $[28,31,37]$.

As a secondary goal, we studied the prognostic potential for the individual parameters (HR, 
SBP, GCS and BD, respectively) to be able to determine the strongest and weakest predictive factors in the initial assessment.

\subsection{Protocol in Study III.}

\subsubsection{Patient selection and data collection}

In our present study, we have focused on patients who suffered severe injuries (ISS $\geq 16$ ), but did not need cardiopulmonal resuscitation on scene. According to these criteria, 9 passengers were selected initially. Two patients were excluded due to their age (9 and 12). One person was transferred from another hospital in a later phase of treatment. The flowchart of patient enrollment is shown on Fig 1.

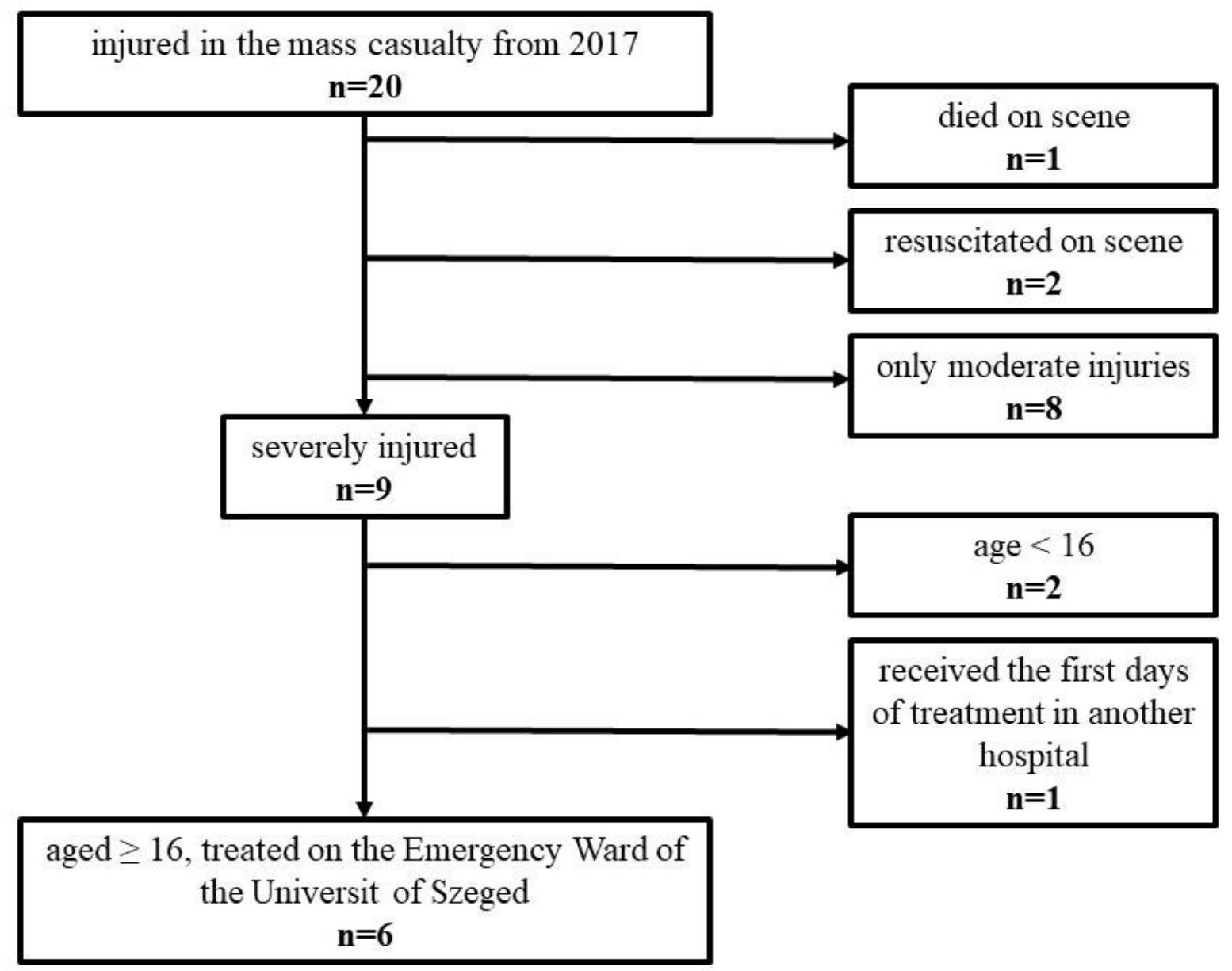

\section{Fig. 1. The flowchart of patient enrollment}

Routinely measured markers of shock, tissue oxygenation and routine labor parameters were collected within the first 6 and 72 hours after injury, and extracted from the electronic database (MedSolution) at the University of Szeged Emergency Department. 


\subsection{Statistical analysis}

In Study I,the results of a detailed questionnaire were evaluated by means of a score systemon a scale from 1-5.Descriptive statistics were made and data were presented as mean values.

In Study IIcontinuous data were expressed as mean \pm standard deviation. Categorical data were expressed as frequency or relative frequency (percentages). Chi-square tests for independence were performed to test the reationship between VS+BD classification result and outcome of mortality. The assumption of chi-square test for independence was slightly violated in the crosstabulation of VS classification result and outcome of mortality, therefore Fisher's exact test was used to test the relationship between VS classification result and outcome of mortality.

Two-proportion Z-test was performed to compare the predictive power of the VS and VS+BD classifications. Binary logistic regression was applied for further analysis between VS+BD classification result (groups 1, 2 vs groups 3,4) and outcome of mortality, oddsratio and $95 \%$ confidence interval for odds-ratio were calculated.

The predictive performance of individual variables was assessed using receiver operating characteristic (ROC) analysis. Area under ROC curve was calculated for each individual variable (candidate predictors: GCS, HR, SBP, BD). Hypothesis tests for AUC ROC were performed and 95\% confidence bounds for AUC ROC were calculated with nonparametric method. A P- value $\mathrm{P}<0.05$ was considered to be statistically significant. All data were analyzed by using statistical software IBM SPSS 25.0 (IBM Corporation, Chicago, IL, USA).

In Study III, data were arranged into a data management software (Sigma Stat 12.0). Descriptive statistical analysis was performed to characterize our patients based on mean and standard deviation (SD) and for data not following the normal distribution, on median and range. Spearman multiple rank correlation was also performed to find any linear relationship between data obtained and then Wilcoxon-test was ran to compare parameters determined at $6 \mathrm{~h}$ and $72 \mathrm{~h}$. On the next step, primary and secondary outcomes will be included as short-term (1 month) mortality, hospital-and ICU length of stay and SIRS, acute organ dysfunctions, multiple organ failure and sepsis. 


\section{RESULTS}

\subsection{Study $I$.}

\subsubsection{The results Hungarian ATLS courses}

Nearly $50 \%$ of the participants came from either a university hospital or the National Institute of Traumatology, thus representing the high levels of Hungarian trauma care. We hope to further spread the concept amongst the lower level centers. Over $80 \%$ of the participants were working in the specialty fields of orthopedics \& trauma, traumatology, anesthesiology \& intensive therapy, and emergency medicine, showing the major specialties participating in trauma care in the Hungarian trauma settings. An educational activity is very accurately judged by the satisfaction of the participants, thus it is very important for every ATLS center. This feedback can assure that the quality of the course remains on the desired level. All of the 305 participants responded positive to the question "Have you learned new and useful information?". It shows that a structured educational strategy can be useful to every participant. Similarly, all of the participants responded positive to the question "Does it worth the time spent on it?" As high as $97 \%$ of the participants thought that the course did worth the course fee.

The skills practices and simulated scenarios are very important parts of the ATLS course, but it is also very important to keep the lectures on a high level of quality. The lectures are evaluated year-to-year to keep that high level. If scores from all years are evaluated at once, none of the lectures get an average grade below 4.6 on a scale of 5 (Fig. 2.). 

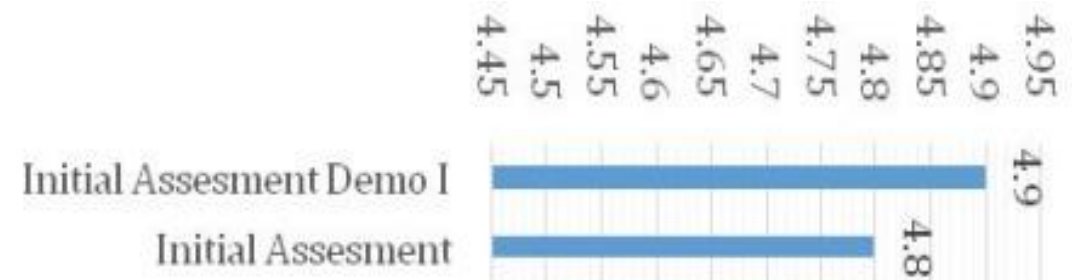

Initial Assesment Demo II

Airway
Shock

Thoracic Trauma

Abdominal Trauma

Surgical Skills Discussion

Surgical Skills Practicum

Station Airway

Station Shock

Station Thoracic X-ray

Pretest Discussion

Head Trauma

Spine

Musculoskeletal

Secondary Survey Demo

Head and Neck Practical

SpineX-ray

Spine Injury Practical

Musculoskeletal Practical
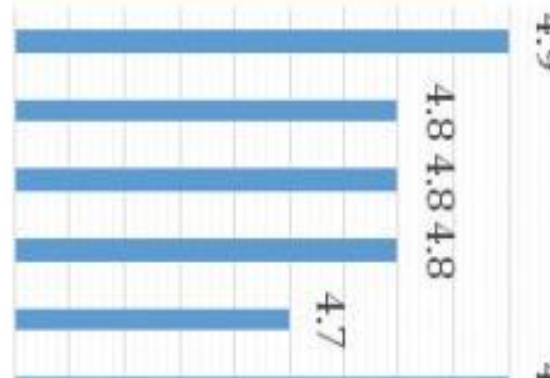

:

$\infty$

$+$

$+$

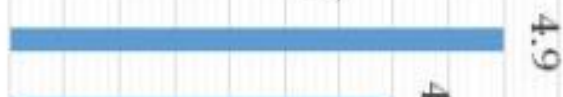

$+6$

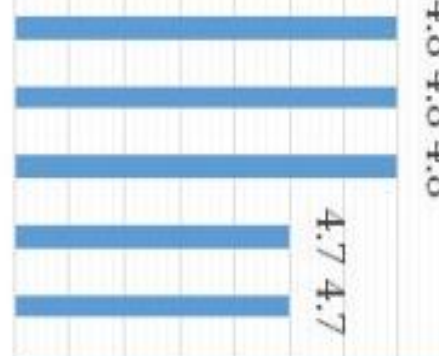

\section{$\infty$}

$+$

$+$

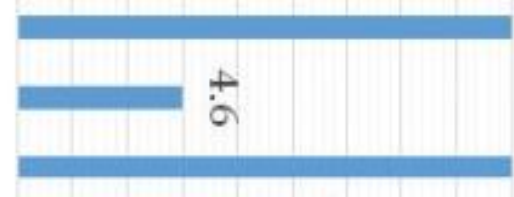

$+5$

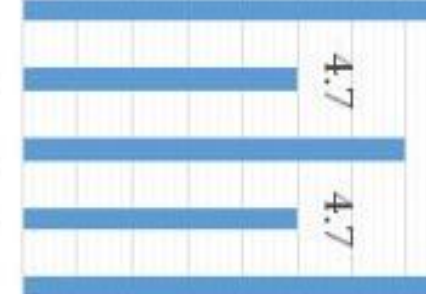

$+\infty$

6

Burn and Cold

Pediatric Trauma

Elderly

Women

Transfer

Triage Scenarios
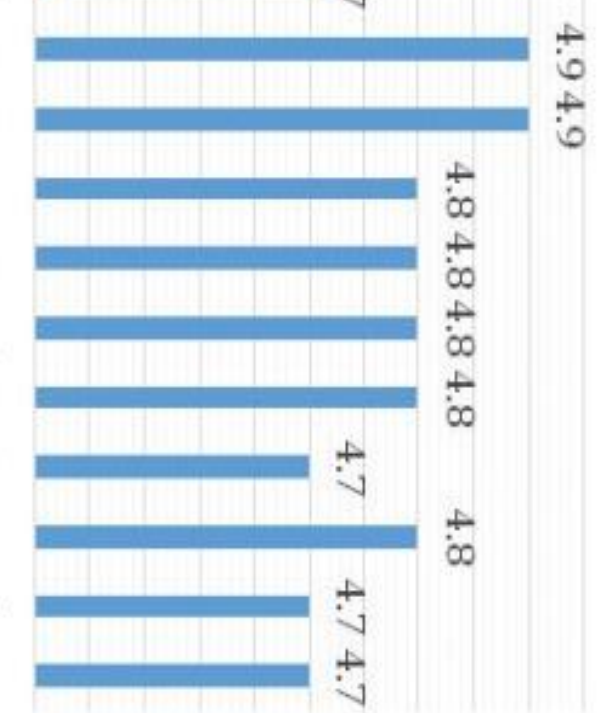

Fig.2. Average grading of the lectures by the participants 


\subsection{Study II.}

\subsubsection{Patient population and demographics}

A total of 684 patients were admitted to our institution with activation of the trauma team. Ultimately, 156 participants met our inclusion criteria. The flowchart for patient enrollment is presented in Figure 3.

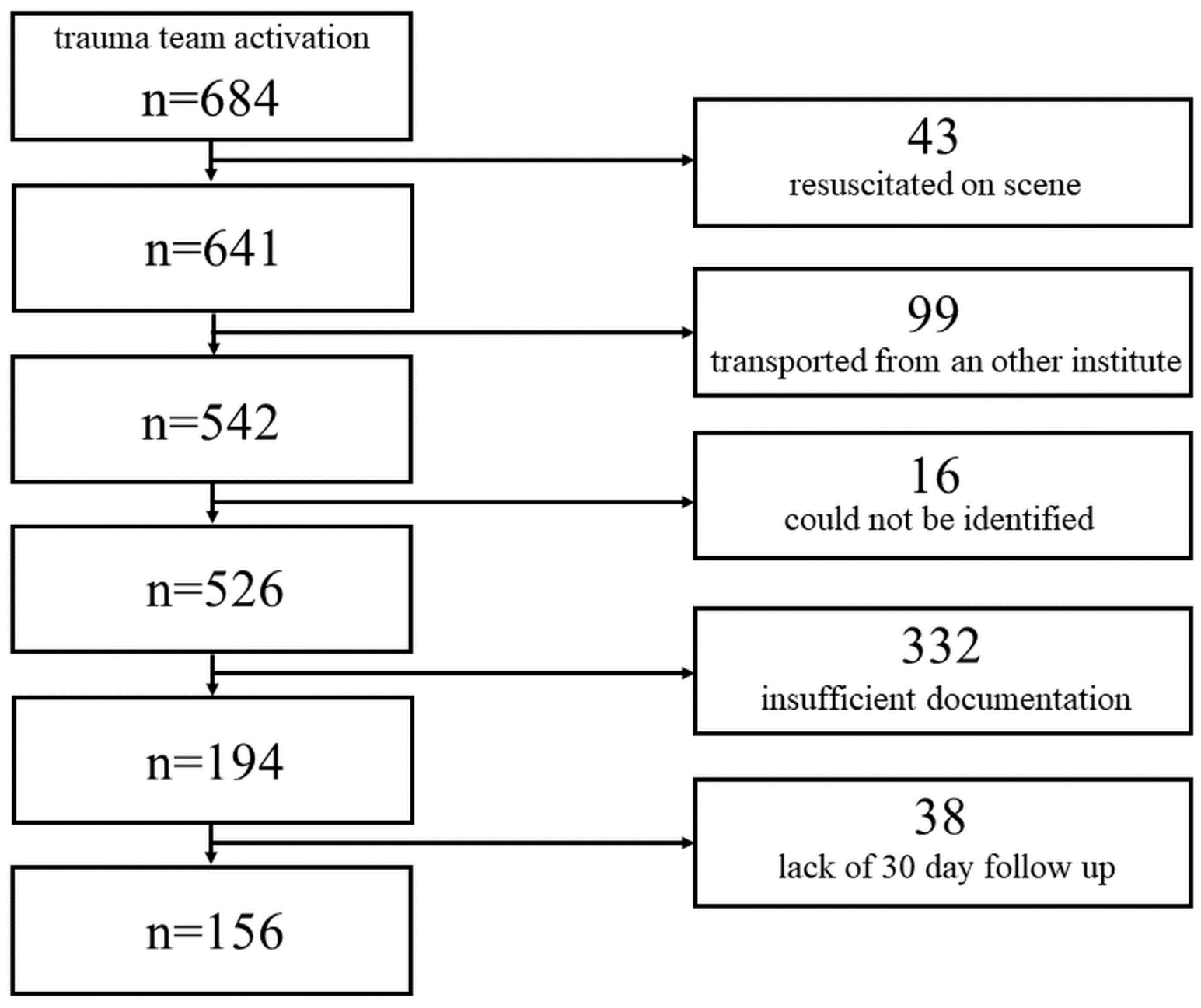

Fig. 3. Study flowchart

The mean age of the participants was $49.4 \pm 20.7$ years, and only $26.7 \%$ of the patients were female. The most common mechanisms of injury were road traffic accidents $(56.4 \%)$ and falls $(29.5 \%)$. The most affected body regions were the head and neck (74.4\%), thorax $(53.9 \%)$, and extremities $(48.1 \%)$. Due to the fact, that most patients suffered a high energy trauma, multiple body regions were involved in several cases. The characteristics of the 24 
patient population are shown in Table 2 .

\begin{tabular}{|c|c|c|c|c|c|c|c|c|c|}
\hline \multirow{2}{*}{ Characteristic } & \multirow{2}{*}{ All classes } & \multicolumn{2}{|c|}{ Class I } & \multicolumn{2}{c|}{ Class II } & \multicolumn{2}{c|}{ Class III } & \multicolumn{2}{c|}{ Class IV } \\
& & VS & VS + BD & VS & VS + BD & VS & VS + BD & VS & VS + BD \\
\hline $\begin{array}{c}\text { Mean Age (y) } \\
\text { (mean } \pm \text { SD) }\end{array}$ & $49.4 \pm 20.7$ & $48.0 \pm 18.7$ & $46.4 \pm 15.2$ & $39.7 \pm 14.8$ & $48.2 \pm 19.9$ & $47.0 \pm 24.3$ & $44.2 \pm 23.9$ & $52.1 \pm 21.2$ & $52.2 \pm 21.3$ \\
$\begin{array}{c}\text { Female (\%) } \\
\text { Male (\%) }\end{array}$ & 26.9 & 30.6 & 33.3 & 20.0 & 23.3 & 23.8 & 26.1 & 26.3 & 26.6 \\
$\begin{array}{c}\text { Mean HR (bpm) } \\
\text { (mean } \pm \text { SD) }\end{array}$ & $82.3 \pm 21.4$ & $78.0 \pm 11.1$ & $79.3 \pm 9.4$ & $90.7 \pm 21.3$ & $81.5 \pm 15.5$ & $88.0 \pm 18.5$ & $84.4 \pm 20.5$ & $82.4 \pm 26.4$ & $82.9 \pm 26.0$ \\
$\begin{array}{c}\text { Mean SBP(Hgmm) } \\
\text { (mean } \pm \text { SD) }\end{array}$ & $125.7 \pm 33.5$ & $142.4 \pm 22.5$ & $144.2 \pm 22.1$ & $119.5 \pm 16.2$ & $137.0 \pm 23.9$ & $130.0 \pm 27.8$ & $127.4 \pm 22.7$ & $114.5 \pm 37.9$ & $115.3 \pm 38.3$ \\
$\begin{array}{c}\text { Mean GCS } \\
\text { (mean } \pm \text { SD) }\end{array}$ & $9.8 \pm 5.5$ & $15.0 \pm 0.0$ & $15.0 \pm 0.0$ & $15.0 \pm 0.0$ & $15.0 \pm 0.0$ & $13.7 \pm 1.0$ & $14.0 \pm 1.0$ & $4.7 \pm 3.3$ & $5.0 \pm 3.6$ \\
$\begin{array}{c}\text { Mean BD } \\
\text { (mmol/L) } \\
\text { (mean } \pm \text { SD) }\end{array}$ & $4.1 \pm 4.9$ & $2.2 \pm 2.1$ & $0.6 \pm 1.0$ & $3.3 \pm 3.6$ & $3.0 \pm 1.7$ & $4.7 \pm 5.6$ & $3.9 \pm 3.2$ & $5.3 \pm 5.6$ & $5.7 \pm 6.0$ \\
$\begin{array}{c}\text { Vasopressor need n } \\
\text { (\%) }\end{array}$ & $36(23.1 \%)$ & $2(4.1 \%)$ & $0(0 \%)$ & $0(0 \%)$ & $1(3.3)$ & $5(23.8)$ & $5(21.7)$ & $29(38.2)$ & $30(38.0)$ \\
\hline
\end{tabular}

Table 2. Patient characteristics. $H R=$ heart rate, $S B P=$ systolic blood pressure, GCS=Glasgow Coma Scale, BD=base deficit, $\mathrm{SD}=$ standard deviation. Slightly declining tendency in mean SBPs, increasing in mean BDs. A large decrease between mean GCS rates of classes II, III and IV, suggesting that GCS might have had the strongest influence on patient allocation. Need for vasopressors occurred mainly in Classes III-IV.

The distribution of injury mechanisms, affected body regions and clinical outcomes are demonstrated in Table 3. 


\begin{tabular}{|c|c|}
\hline Injury severity & Patient population $(n=156)$ \\
\hline ISS median (IQR) & $29(20-34)$ \\
\hline$A I S_{\text {head, neck }} \geq 3 n(\%)$ & $47(30.1)$ \\
\hline$A I S_{f a c e} \geq 3 n(\%)$ & $6(3.9)$ \\
\hline$A I S_{\text {chest }} \geq 3 n(\%)$ & $44(28.2)$ \\
\hline$A I S_{\text {abdomen, pelvic contents }} \geq 3 n(\%)$ & $24(15.4)$ \\
\hline$A I S_{\text {extremities, pelvic girdle }} \geq 3 n$ (\%) & 51 (32.7) \\
\hline$A I S_{\text {external }} \geq 3 n(\%)$ & $3(1.9)$ \\
\hline \multicolumn{2}{|l|}{ Mechanism of injury $n(\%)$} \\
\hline Road traffic accidents & $88(56.4)$ \\
\hline Pedestrian & $18(20.5)$ \\
\hline Bicicle & $16(18.2)$ \\
\hline Motorcycle & $17(19.3)$ \\
\hline Automobile & $37(42.1)$ \\
\hline Falls & $46(29.5)$ \\
\hline Assault & $6(3.9)$ \\
\hline Self harm & $3(1.9)$ \\
\hline Other & $13(8.3)$ \\
\hline \multicolumn{2}{|l|}{ Affected body regions $\mathrm{n}(\%)$} \\
\hline Head & $116(74.4)$ \\
\hline Fracture of the skull & $24(20.7)$ \\
\hline Concussion & $14(12.1)$ \\
\hline Intracranial hemorrhage & $47(40.5)$ \\
\hline Subdural bleeding & $21(44.7)$ \\
\hline Epidural bleeding & $7(14.9)$ \\
\hline Subarachnoid hemorrhage & $19(40.4)$ \\
\hline Thorax & $84(53.9)$ \\
\hline Pneumothorax & $37(44.1)$ \\
\hline Hemothorax & $9(10.7)$ \\
\hline Lung contusion & $4(4.8)$ \\
\hline Abdomen and pelvis & $49(31.4)$ \\
\hline Inraabdominal organ injury & $18(36.7)$ \\
\hline Injury of the spleen & $13(72.2)$ \\
\hline Injury of the liver & $5(27.8)$ \\
\hline Pelvic or retroperitoneal organ injury & $6(12.2)$ \\
\hline Kidney injury & $6(100.0)$ \\
\hline Pelvic or sacral fracture & $25(16.0)$ \\
\hline Isolated pubic ramus fracture & $6(24.0)$ \\
\hline Isolated iliac wing fracture & $1(4.0)$ \\
\hline Isolated sacral fracture & $2(8.0)$ \\
\hline Open book injury & $4(16.0)$ \\
\hline Lateral compression injury & $11(44.0)$ \\
\hline Unilateral complete posterior disruption & $1(4.0)$ \\
\hline Extremities & $75(48.1)$ \\
\hline Shoulder or upper arm & $23(30.7)$ \\
\hline Elbow or forearm & $19(25.3)$ \\
\hline Wrist or hand & $14(18.7)$ \\
\hline Hip or thigh & $26(34.7)$ \\
\hline Knee or leg & 35 (46.7) \\
\hline Ankle or feet & $6(8.0)$ \\
\hline Spine & $40(25.6)$ \\
\hline Fracture of the cervical spine & $4(10.0)$ \\
\hline Fracture of the thoracal spine & $11(27.5)$ \\
\hline Fracture of the lumbar spine & $25(62.5)$ \\
\hline \multicolumn{2}{|l|}{ Outcomes n (\%) } \\
\hline Administration of blood products & $97(62.2)$ \\
\hline Massive transfusion & $27(17.3)$ \\
\hline Administration of vasopressors & $36(23.1)$ \\
\hline Need for ICU admission & $111(71.2)$ \\
\hline Surgery in the first $24 \mathrm{~h}$ & $89(57.1)$ \\
\hline Mortality in the first $24 \mathrm{~h}$ & $16(10.3)$ \\
\hline Mortality in the first $30 \mathrm{~d}$ & $34(21.8)$ \\
\hline
\end{tabular}


Table 3. Severity and mechanisms of injury, affected body regions, outcomes. ISS=Injury Severity Score, AIS=Abbreviated Injury Scale, IQR=interquartile range, ICU=Intensive Care Unit. AIS coding was performed based on AIS 2008 dictionary. Road traffic accidents and falls were the most common mechanisms that required the activation of the trauma team. The regions of the head and neck, thorax, and extremities were involved in a high number of cases. More than half of the participants underwent surgery in the first 24 hours. Blood products were administered in 97 cases. 34 patients died within 30 days, resulting in a mortality rate of $21.8 \%$.

\subsubsection{Results of statistical analyses}

According to VS, $31.4 \%$ of the patients were assigned to class I, $6.4 \%$ to class II, $13.5 \%$ to class III and $48.7 \%$ to class IV. Based on VS+BD criteria, $16.0 \%$ of the patients were reallocated to a higher severity class; however, this change affected mostly the low-risk classes (I and II). 34 patients died within the first 30 days, resulting in a mortality rate of $21.8 \%$. The distribution of patients and mortality among the classes are shown in Figure 4.
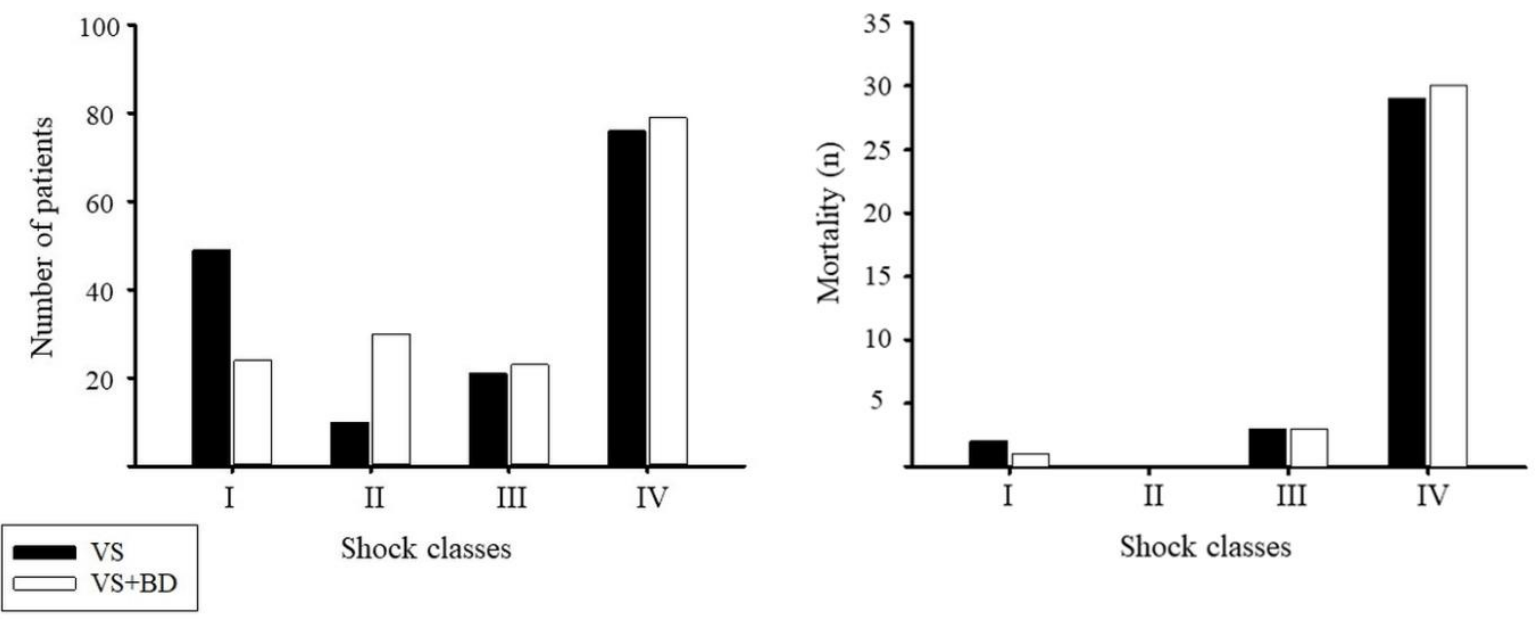

Fig. 4. Distribution of patients (A) and mortality (B) among the severity classes based on VS and VS+BD. 
Both the VS and VS+BD classifications showed a strong relation to mortality (chi-square and Fisher's exact tests $P_{\mathrm{VS}}=0.0001$ vs. $P_{\mathrm{VS}+\mathrm{BD}}=0.000009$, respectively). These results are shown in Tables 4 and 5. According to the two-proportion Z-test, there was no significant difference in their predictive performance of mortality $(P=0.9808)$.

\begin{tabular}{cc|ccc}
\hline Variables & Shock classes & Survival & Exitus & Total \\
\hline HR; SBP; GCS & I & 47 & 2 & 49 \\
& II & 10 & 0 & 10 \\
& III & 18 & 3 & 21 \\
& $I V$ & 47 & 29 & 76 \\
\hline Total & 122 & 34 & 156 \\
\hline $\begin{array}{c}\text { Fisher's exact } \\
\text { test }\end{array}$ & & P-value \\
\hline
\end{tabular}

Table 4. Fisher's exact test of VS and mortality. The results demonstrate a strong relation between mortality and VS classification. A p-value $\mathrm{p}<0.001$ was considered to be statistically significant at 0.001 level. $\mathrm{HR}=$ heart rate, $\mathrm{SBP}=$ systolic blood pressure, GCS=Glasgow Coma Scale, df=degrees of freedom. Survival and death refer to 30-day mortality.

\begin{tabular}{cc|ccc}
\hline Variables & Shock classes & Survival & Exitus & Total \\
\hline HR; SBP; GCS; & I & 23 & 1 & 24 \\
BD & II & 30 & 0 & 30 \\
& III & 20 & 3 & 23 \\
& IV & 49 & 30 & 79 \\
\hline Total & & 122 & 34 & 156 \\
\hline Pearson-Chi & df & & P-value & \\
square & 3 & & $0.000^{*}$ & \\
\hline
\end{tabular}

Table 5. Chi-square test of VS+BD and mortality. Survival and death refer to 30-day mortality. The results demonstrate a strong relation between mortality and VS+BD classification. A p-value $\mathrm{p}<0.001$ was considered to be statistically significant at 0.001 
level.HR=heart rate, $\mathrm{SBP}=$ systolic blood pressure, $\mathrm{GCS}=$ Glasgow Coma Scale, $\mathrm{BD}=$ base deficit, $\mathrm{df}=$ degrees of freedom.

Through a separate analysis of HR, SBP, GCS and BD, we found that GCS has the highest prognostic power $\left(\mathrm{AUC}_{\mathrm{GCS}}=0.799, P<0.001\right.$; CI [0.722, 0.875]). Derangements in BD and SBP were significant but weak predictors of mortality $\left(\mathrm{AUC}_{\mathrm{BD}}=0.683, P=0.001\right.$, CI [0.576, 0.790]; $\mathrm{AUC}_{\mathrm{SBP}}=0.633, P=0.018$, CI $\left.[0.521,0.744]\right)$. HR was found ineffective in prognosis $\left(\mathrm{AUC}_{\mathrm{HR}}=0.595, \mathrm{P}=0.090, \mathrm{CI}[0.480,0.710]\right)$. The results of the ROC analysis with the ROC curves for the variables are shown in Fig. 5.

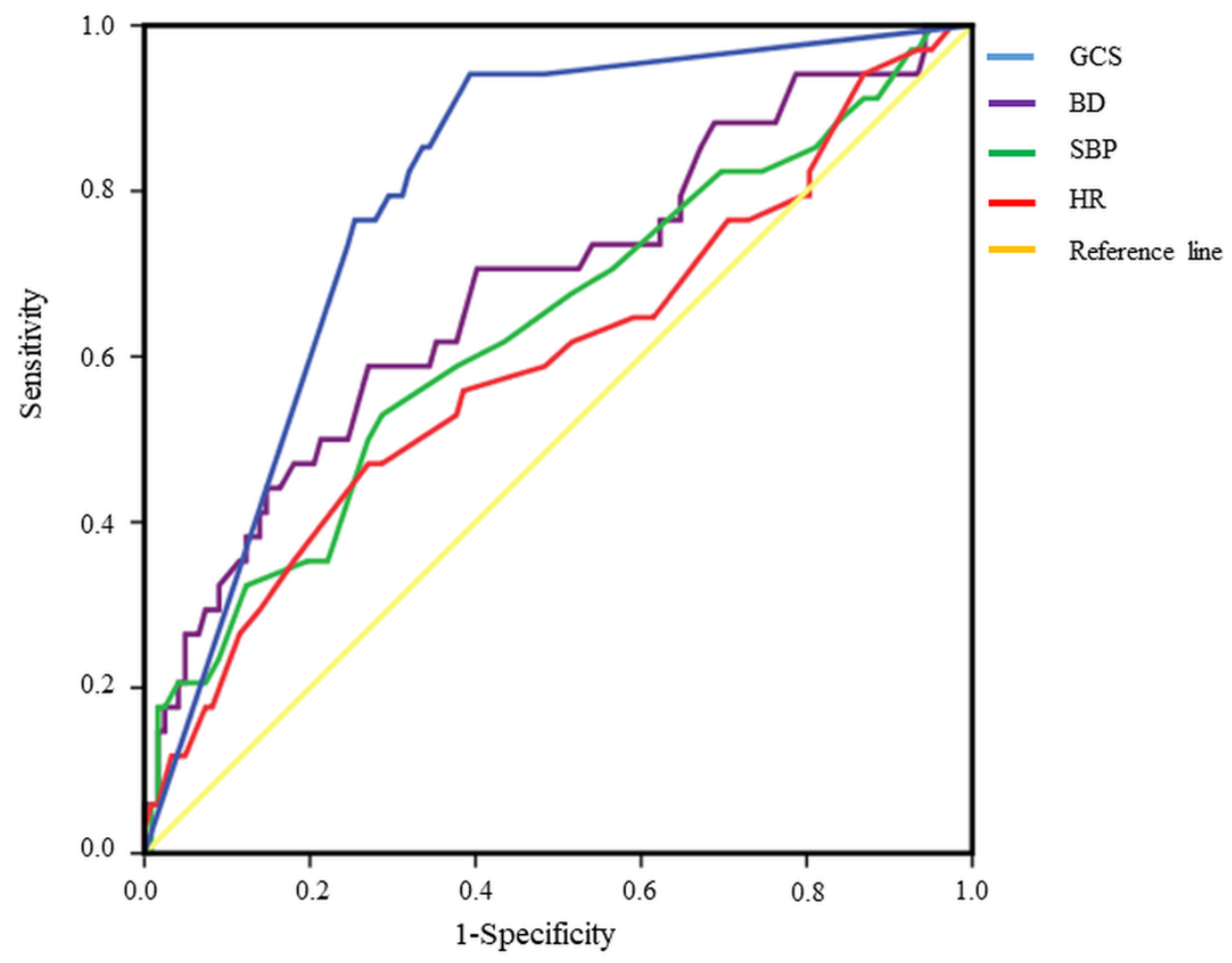

Diagonal segments are produced by ties

\begin{tabular}{|c|c|c|c|c|}
\hline \multirow[b]{2}{*}{ Variables } & \multirow[b]{2}{*}{ AUC (ROC) } & \multirow[b]{2}{*}{$P$-value } & \multicolumn{2}{|c|}{ 95\% Confidence Interval } \\
\hline & & & Low er bound & Upper bound \\
\hline HR & 0.595 & 0.090 & 0.480 & 0.710 \\
\hline$S B P$ & 0.633 & $0.018^{*}$ & 0.521 & 0.744 \\
\hline GCS & 0.799 & $0.000^{*}$ & 0.722 & 0.875 \\
\hline$B D$ & 0.683 & $0.001 *$ & 0.576 & 0.790 \\
\hline
\end{tabular}

\section{Fig. 5. ROC analysis of the individual variables}

The binary logistic regression analysis confirmed that the risk for mortality increases massively in the higher severity classes (III and IV) as compared to the less severe ones (I and II). The results of the analysis are demonstrated inTable 6. 


\begin{tabular}{|l|c|c|c|c|}
\hline & \multirow{2}{*}{ Significance } & \multirow{2}{*}{ OR } & \multicolumn{2}{|c|}{$95 \%$ CI } \\
\cline { 4 - 5 } & & Lower & Upper \\
\hline Class I,II vs III,IV & $0.002 *$ & 25.348 & 3.358 & 191.346 \\
\hline
\end{tabular}

Table 6. Binary logistic regression between VS+BD classification result (class I, II vs class III, IV) and outcome of mortality. The risk for mortality increases massively in the higher shock (III, IV) compared to the less severe ones (I, II). OR=Odds Ratio, $\mathrm{CI}=$ Confidence Interval.

\subsection{Study III.}

\subsubsection{Patient characteristics}

The mean age of the included patients was 34.85 years, and the mean ISS was 36.83 . The baseline characteristics of patients are shown in Table 7.

\begin{tabular}{|c|c|c|}
\hline Demographics and outcomes & & \\
\hline Age mean $\pm \mathrm{SD}$ & \multicolumn{2}{|c|}{$34.85 \pm 2.97$} \\
\hline Male $\% \%$ & \multicolumn{2}{|c|}{83.44} \\
\hline ISS mean & \multicolumn{2}{|c|}{$36.83 \pm 14.93$} \\
\hline ISS median [IQR] & \multicolumn{2}{|c|}{31.5 [27.5-37] } \\
\hline Mortality (\%) & \multicolumn{2}{|c|}{16.66} \\
\hline Clinical parameters & $\begin{array}{c}6 \text { hours post- } \\
\text { injury }\end{array}$ & $\begin{array}{l}72 \text { hours post- } \\
\text { injury }\end{array}$ \\
\hline Base excess $(\mathrm{mmol} / \mathrm{l})$ mean $\pm \mathrm{SD}$ & $-2.13 \pm 2.90$ & $0.47 \pm 3.09$ \\
\hline Lactate $(\mathrm{mmol} / \mathrm{l})$ mean $\pm \mathrm{SD}$ & $3.23 \pm 1.50$ & $1.27 \pm 0.67$ \\
\hline $\mathrm{WBC}(\mathrm{G} / \mathrm{L})$ mean $\pm \mathrm{SD}$ & $18.69 \pm 6.22$ & $7.56 \pm 0.91 *$ \\
\hline $\mathrm{PLT}(\mathrm{G} / \mathrm{L})$ mean $\pm \mathrm{SD}$ & $251.83 \pm 80.99$ & $126.00 \pm 19.15^{*}$ \\
\hline Creatinine $(\mu \mathrm{mol} / \mathrm{l})$ mean $\pm \mathrm{SD}$ & $88.00 \pm 13.58$ & $63.5 \pm 5.97^{*}$ \\
\hline Bilirubin $(\mu \mathrm{mol} / \mathrm{l})$ mean $\pm \mathrm{SD}$ & $10.34 \pm 1.32$ & $24.73 \pm 17.51$ \\
\hline $\mathrm{AST}(\mathrm{U} / \mathrm{l})$ mean $\pm \mathrm{SD}$ & $79.4 \pm 20.05$ & $70.33 \pm 26.57$ \\
\hline $\mathrm{ALT}(\mathrm{U} / \mathrm{l})$ mean $\pm \mathrm{SD}$ & $64.4 \pm 22.26$ & $51.33 \pm 34.36$ \\
\hline GGT $(\mathrm{U} / \mathrm{l})$ mean $\pm \mathrm{SD}$ & $29.6 \pm 18.42$ & $19.67 \pm 14.22$ \\
\hline
\end{tabular}


Table 7. Patient characteristics, outcomes, clinical parameters 6 and 72 hours postinjury

The most affected body regions were the chest, pelvis and extremities. Pneumothorax occurred in 3 from the 5 included patients. Traumatic Brain Injury (TBI) was present in 2 cases, while only one person had a significant abdominal injury.

Significant negative correlation demonstrated between 6-hour WBC and 72-hour creatinine levels ( $r s=-0.949 ; p=0.0167)$ and between 6-hour PLT and 72-hour creatinine levels ( $\mathrm{rs}=$ $0.876 ; \mathrm{p}=0.0833$ ), these changes may have predictive power when examined in combination. (Fig. 6.).

Examining the change in routine laboratory parameters measured at 6 and 72 hours postinjury over the time interval between the two samples, PLT, WBC, and creatinine levels showed significant changes. (Fig. 6.).
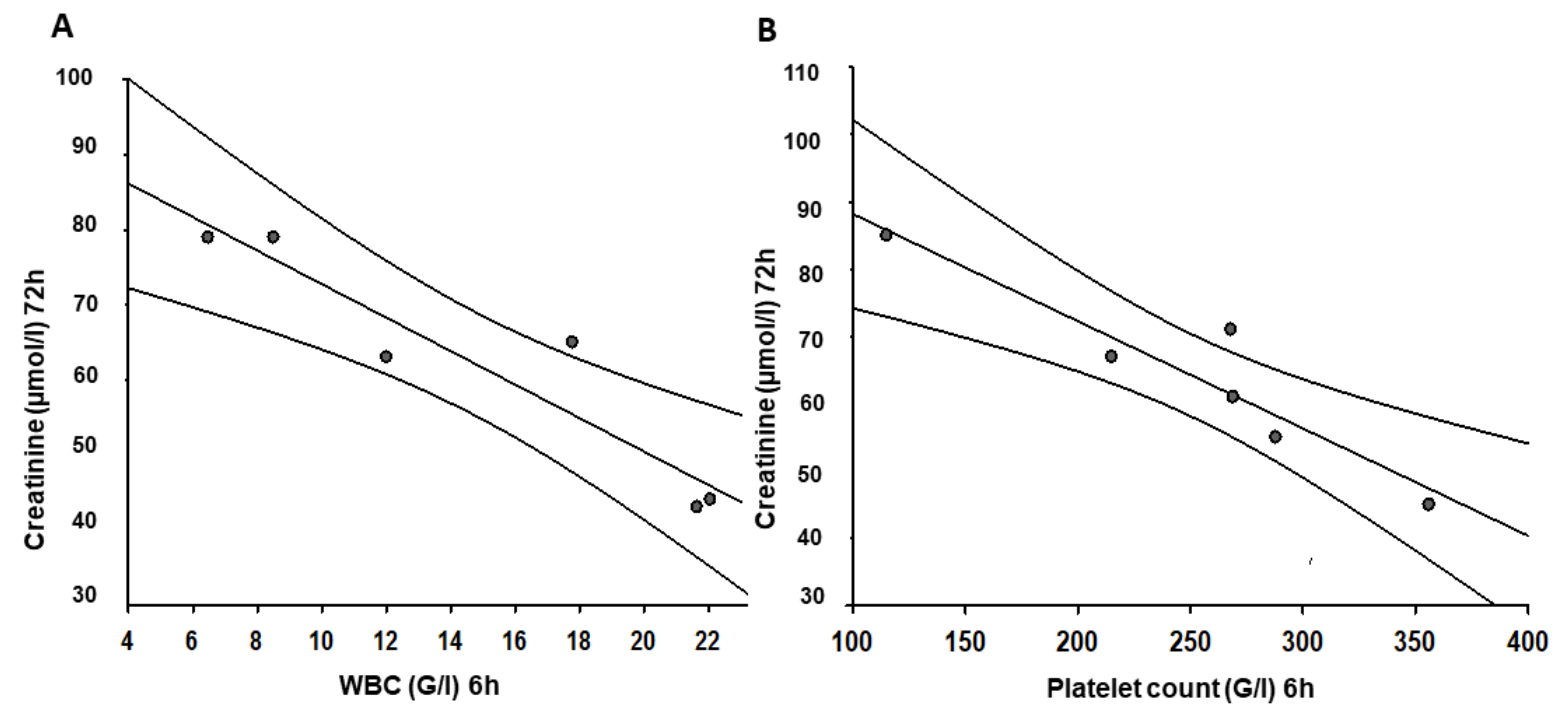

Fig. 6. The injuries of the individual patients are listed. 


\section{DISCUSSION}

\subsection{Impact of Hungarian ATLS courses on trauma care}

As of 2015, Hungary is still one of the only three countries from Eastern Europe to have an ATLS program, the other two countries being Lithuania and Slovenia [57]. The 20th Hungarian course is going to be held in December, 2015. The instructors' program is also successfully running with about $25 \%$ of the participants showing instructor potential and 3 instructor courses held throughout the years. Szeged is until 2015 was the only ATLS center in Hungary, organizing 2 courses every year for 16 participants a course. In 2016 launched the second course venue in Budapest to get possibility of 4 courses per year. Since 2013, successful completion of an ATLS course is a prerequisite for the Hungarian state board examination in orthopedics \& trauma surgery. Also, as the Hungarian emergency system is shifting to establishing central Emergency Departments replacing the old, separated emergency system for the different specialties, more-and-more residents are going to start in the field of emergency medicine, with the possibility of the ATLS course becoming a prerequisite for the board examination in emergency medicine as well. These two facts indicate that the interest in the course is going to significantly rise in the near future. The Szeged center with 2 courses a year is not going to be able to deal with this load thus, opening 2 new course sites in other Hungarian trauma centers is compelling. Investigating the impact of ATLS on the quality of Hungarian trauma care would be very challenging; however, after 20 successful courses and 305 participants, there are some interesting data about the Hungarian ATLS program. It is very important to make the idea and concept of the training spread in the Hungarian trauma system. As nearly half of the participants were under 30, and as completion of an ATLS course is now a prerequisite for obtaining an orthopedics \& trauma certification, we can hope that the front line of the near future of the Hungarian trauma system will bear the skills and foundations required for a state-of-the-art approach.

Participant's failure is also a very important aspect of a medical educational course. Only a bit over $3 \%$ of the participants failed to pass, and less than $10 \%$ had to retake either the MCQ or the practice examination. These points to the fact that until recently, taking the course was not obligatory, thus all participants were motivated. It is going to be interesting to see if the failure rate changes with the course becoming a prerequisite for the orthopedics $\&$ trauma board examination, and possibly for the emergency medicine board examination as well. As skills-centered, practice-based, structured education gains more and more 32 
territory in both undergraduate and graduate medical education, we hope that we can build on the success of the Hungarian ATLS program and that these efforts lead to further improvement of the Hungarian trauma system.

\subsection{Comparison of the current and previous ATLS classifications}

This study was designed to investigate the previous, VS-based and the current ATLS classifications and the prognostic power of the parameters. Both classifications were highly effective in predicting mortality, with no significant difference between their prognostic values. Therefore, the superiority of VS+BD over the VS classification could not be confirmed.

Some other findings are also noteworthy, as we have demonstrated that more than $90 \%$ of all deaths were distributed in classes III and IV. This data underlines the importance of the threshold between classes II and III, where the first derangements in SBP, respiratory rate and urinary output usually occur [26]. According to other studies, the threshold BD value between these two classes $(6 \mathrm{mmol} / \mathrm{L})$ shows a notable predictive potential for mortality and transfusion requirements post-injury $[36,42,58,59] .6 \mathrm{mmol} / \mathrm{L}$ is also the threshold from where the administration of blood products is recommended by ATLS [26]. The therapeutic and prognostic relevance of this point questions the reasonability of dividing trauma patients into four different severity groups. Additionally, due to the need for rapid decisions in the emergency trauma setting, the complexity of the ATLS shock classification has already received criticism before its extension with the BD [60]. Based on our study, combining the less severe classes (I and II) and the severe classes (III and IV) could be a legitimate option to increase the practicality of the classification. Of course, a simplified classification like this should always be evaluated together with the adjuncts of the primary survey (e.g. extended Focused Assessment with Sonography for Trauma (eFAST) and pelvic X-ray). During the secondary survey, trauma patients could undergo a comprehensive, detailed assessment to estimate the extent of optimal fluid replacement.

As a secondary outcome, the predictive values of the individual variables were evaluated. GCS, BD and SBP showed a significant predictive performance. While GCS displayed a relatively strong relation to the outcome, the relation was weak for BD and SBP. In our study, BD and SBP alone did not appear to have a sufficiently high prognostic potential to be the foundation for the early assessment. According to other studies, SBP is considered to have a poor reliability in the early assessment, since hypotension usually does not occur until the degree of shock is profound [23,61]. Despite of its strong relation to mortality, 33 
GCS can be affected by several factors besides hypotension, such as traumatic brain injury or alcohol intoxication [62].

Of note, HR did not have a significant relation to mortality in our study. Numerous factors such as anxiety, pain, medication and spinal cord injury can lead to elevated HR, making the specificity of tachycardia for hypotension questionable [62,63]. Increased HR may also be masked via beta blockers [64,65] (particularly in combination with Ca2+-channel inhibitors and ACE inhibitors) or physiological bradycardia [60]. Multiple studies pointed out that HR tends to demonstrate a biphasic response to bleeding since the patients develop bradycardia as blood loss becomes profound after initial tachycardia [61,66,67]. In our study, the predictive values of the individual variables showed the following ranking: $\mathrm{GCS}>\mathrm{BD}>\mathrm{SBP}>\mathrm{HR}$. The relevant differences between the variables suggest that weighing them and using their combination to allocate trauma patients could potentially increase the accuracy and specificity of the classification for hemorrhage. However, further research with larger sample size is required to elaborate such modifications.

Limitations of this study are coming from its retrospective nature. Although our cohort analysis with the given sample size only has limited value as a validation study, it provides original research information in a controversial topic and highlights potential areas of improvement for an assessment tool that is mistrusted by several clinicians [28].

With regard to GCS upon admission, the concern emerges whether prehospital intubation had a major influence on patient allocation. In accordance with the paramedics protocol, onscene intubation is indicated in case of $\mathrm{GCS}<8$, which already entails the allocation into class IV according to the criteria of shock classification used in our study. Consequently, the distortional effect of prehospital intubation on our results is not likely.

The use of vasopressors occurred mostly in classes III-IV, thus having less influence on our results. The notable amount of excluded patients and our unability to include respiratory rate and urinary output in the analysis are due to the lack of comprehensive documentation. In conclusion, despite the significant relationship between BD and mortality, the previous and current ATLS classifications yielded nearly equivalent predictive performances, thereby rendering the added value of BD to the classification questionable. Undoubtedly, post-injury vital sign values are continuously changing during trauma care and individual reactions can vary greatly. Despite these facts, trends may appear in the derangements of physiological variables. In this study, the capability of individual variables to predict mortality followed the GCS $>\mathrm{BD}>\mathrm{SBP}>\mathrm{HR}$ ranking. The role of HR in the early assessment 
of trauma patients may worth reconsideration in further studies since it does not seem to reflect the clinical condition accurately. Although the ATLS shock classification is not necessarily a pragmatic scale, it has become taught in more than 60 countries, making an impact on the approach of young clinicians to the initial management of the severely injured. Taking these considerations is into account, striving for the further targeted clicinal investigations and the development of the classification may be advantageous.

\subsection{Mass casualty accident highlighting the need for a Hungarian trauma registry}

Our current study is a call for the establishment of a national trauma registry in Hungary. In order to demonstrate the potential in having a registry, we presented one mass casualty and raised attention to new probable predictive factors in trauma that are waiting for validation. Many of the systemic responses to severe injury are already well known. Directly after trauma, classical markers of tissue injury are released, including "alarm" molecules with high immunomodulatory potential and hyperacute pro-inflammatory cytokines, such as tumor necrosis factor- $\alpha$ (TNF- $\alpha)$, or interleukin-1 $\beta$ (IL-1 $\beta)$. The release of these components results in Toll-like receptor (TLR) activation with an effect after 1-2 h [68]. In the more comprehensive analysis of this phase, on-scene blood sampling would be enormously helpful. After the hyperacute stage, early or subacute cytokines including IL-6, IL-8 as well as IL-12 and IL-18, chemokines and leukocytes migratory factors drive an exaggerated activation of polymorphonuclear leukocytes, and the increased production of reactive oxygen species (ROS) which both heavily contribute to the clinical outcome [69]. The peak of these responses does not start within the first 4 hours from the initial insult and occurs at approximately $12 \mathrm{~h}[51,52]$. Consequently, a blood sampling around the 6th hour seems to be applicable for the analysis of the early stage. It is also widely accepted that the initial pro-inflammatory phase switches later to an anti-inflammatory phases with extended anti-inflammatory cytokine release to facilitate regenerative processes, however the proinflammatory and anti-inflammatory forces may ultimately amplify each other, creating a state of increasingly destructive immunologic dissonance [70]. It may lead to severe complications such as SIRS, and the overstimulation may result in early multiorgan failure (MOF) within 72 hours after injury [48]. Hence, we aimed to examine the early and late phases simultaneously in order to find predictive factors for the clinical outcome.

Platelet count and serum creatinine level are widely used predictors for several health conditions [71-73]. Nouér et al. analyzed patients with multiple myeloma and found that both higher platelet counts and higher serum creatinine levels were accompanied by a 35 
higher rate of invasive aspergillosis [74]. In the study of Le et al., thrombocytopenia independently predicted death in idiopathic pulmonary arterial hypertension [72]. Kertai et al. revealed a significant association between postoperative nadir platelet counts, and acute kidney injury, and short-term mortality after Coronary Artery Bypass Grafting (CABG) surgery [75]. In the trauma setting, close to $20 \%$ of the significantly injured develop thrombocytosis according to Salim et al. [76]. Elevated platelet count is considered to be associated with increased risk of complications during recovery, but also with a decreased mortality rate and therefore may have overall protective effect [76,77].

Through the analysis of the acute and late phases of the injury-accompanied inflammation, we have found a strong relation between total leukocyte and platelet counts, and serum creatinine levels. According to our results, the combination of these parameters might have a predictive potential for unfavorable outcomes after injury. For a comprehensive analysis on a large cohort, the establishment of a national trauma registry is needed.

A registry contains uniform medical and demographic data on individuals who meet specific inclusion criteria. Data are documented in an ongoing and systematic manner in order to serve predetermined purposes [78]. Generally, registries require good planning in order to be successful. The collection of a large amount of unnecessary data can be avoided through the accurate identification of the main purpose of the registry and the thorough cost/benefit evaluation of each and every probable parameter. The core data set, patient outcomes and the target population have to be clear and unambiguous. As another important aspect, the available financial and human resources must be appraised and the key stakeholders should be identified [79]. Besides these basic consideration, several minor details must be discussed in advance. Establishing a registry is a highly demanding teamwork that requires dedication, but also has the potential for being the starting point of significant scientific results. In order to lay these foundations in Hungary, the close cooperation of leading clinicians from our level I trauma centers is needed. 


\section{SUMMARY OF NEW FINDINGS}

Our brief overview about the Hungarian ATLS program have shown a high level of satisfaction amongst the participating doctors. Most participants are working in higher level centers. According to the participants the program has good quality. Our study emerged further need to establish at least one more new center to provide the adequate number of courses for every professional interested in it or required to take it.

Our findings provided supportive data for the currently used ATLS shock classification does not appear to be superior to the VS-based previous classification. GCS, BD and SBP are useful parameters to predict the prognosis. Changes in HR do not reflect the clinical course accurately, thus further studies will be needed to determine the value of this parameter in trauma-associated hypovolemic-hemorrhagic shock conditions.

As a result of our investigations, we could underline the need for a national trauma registry in Hungary through presenting a mass casualty, and the thoughts generated by it. Simultaneous changes in early leukocyte and platelet counts, and creatinine levels might have a significant predictive potential for unfavorable outcomes in trauma care according to this isolated case series. However, a structured, consensual way of data collection and large patient population are required in order to validate such speculations. For this purpose, we suggest the establishment of a national trauma registry in our country. Despite the demanding nature of this project, we believe that our goal can be reached through the collaboration of our clinicians and scientists. 


\section{ACKNOWLEDGMENTS}

I am grateful to Professor Endre Varga for supporting my scientific and clinical career and giving me the opportunity to carry out my scientific and clinical work in the Department of Traumatology with his valuable scientific guidance and assistance. I am also grateful to Dr. Petra Hartmann, who provided me with assistance in completing my studies and writing my publications. Additionally, I am thankful to Dr. Eszter Tuboly and Dr. Péter Jávor, who also helped me in collecting, processing and publishing scientific information. I would also like to thank all the colleagues of the Department of Traumatology for providing a stable background and helping me with my healing work and the Hungarian ATLS Working Group for helping me with my teaching work. 


\section{References}

[1] American College of Surgeons. Advanced trauma life support for doctors. Student course manual. 10th ed. Chicago, Illinois: American College of Surgeons; 2018.

[2] American College of Surgeons. Advanced trauma life support for doctors. Student course manual. 9th ed. Chicago, Illinois: American College of Surgeons; 2012.

[3] Mohammad, A.; Branicki, F.; Abu-Zidan, F.M. Educational and clinical impact of Advanced Trauma Life Support (ATLS) courses: a systematic review. World $J$ Surg. 38:322-9. 2014.

[4] Jayaraman, S.; Sethi, D.; Chinnock, P. et al. Advanced trauma life support training for hospital staff. Cochrane Database Syst Rev. 8:CD004173. 2014.

[5] Hashmi, Z.G.; Haider, A.H.; Zafar, S.N. et al. Hospital-based trauma quality improvement initiatives: first step toward improving trauma outcomes in the developing world. J Trauma Acute Care Surg. 75(1):60-8. 2013.

[6] Hedges, J.R.; Adams, A.L.; Gunnels, M.D. ATLS practices and survival at rural level III trauma hospitals, 1995-1999. Prehosp Emerg Care.6(3):299-305. 2002.

[7] Williams, M.J.; Lockey, A.S.; Culshaw, M.C. Improved trauma management with advanced trauma life support (ATLS) training. J Accid Emerg Med. 14(2):81-3. 1997.

[8] Evans, J.A.; van Wessem, K.J.P.; McDougal, D. et al., Epidemiology of traumatic deaths: comprehensive population-based assessment. World J Surg.34(1): p. 158-63.2010.

[9] Frohlich, M.; Driessen, A.; Böhmer, A. et al. Is the shock index based classification of hypovolemic shock applicable in multiple injured patients with severe traumatic brain injury?-an analysis of the TraumaRegister DGU ${ }^{\circledR}$. Scand J Trauma Resusc Emerg Med.24:148. 2016.

[10] Oka, Y.; Murata, A.; Nishijima, J.et al., Circulating interleukin 6 as a useful marker for predicting postoperative complications. Cytokine.4(4): p. 298-304.1992.

[11] Chen, G.Y.; Nuñez, G.Sterile inflammation: sensing and reacting to damage.Nat Rev Immunol.10(12): p. 826-37.2010.

[12] Hemmila, M.R.; Cain-Nielsen, A.H.; Wahl, W.L.et al., Regional collaborative quality improvement for trauma reduces complications and costs.J Trauma Acute Care Surg.78(1): p. 78-85; discussion 85-7.2015.

[13] Butcher, N.E.; D'Este, C.; Balogh, Z.J. The quest for a universal definition of polytrauma: A trauma registry-based validation study. J. Trauma Acute Care Surg. 77:620623. 2014.doi: 10.1097/TA.0000000000000404.

[14] Boyd, C.R.; Tolson, M.A.; Copes, W.S. Evaluating trauma care: The TRISS method. Trauma Score and the Injury Severity Score. J. Trauma. 27:370-378. 1987. doi: 39 
[15] Sikand, M.; Williams, K.; White C. et al. The financial cost of treating polytrauma: Implications for tertiary referral centres in the United Kingdom. Injury. 36:733-737. 2005.doi: 10.1016/j.injury.2004.12.026.

[16] Biewener, A.; Aschenbrenner, U.; Rammelt, S. et al. Impact of helicopter transport and hospital level on mortality of polytrauma patients. J. Trauma. 56:94-98. 2004. doi: 10.1097/01.TA.0000061883.92194.50.

[17] Hildebrand, F.; Giannoudis, P.; Kretteck, C. et al. Damage control: Extremities. Injury. 35:678-689. 2004.doi: 10.1016/j.injury.2004.03.004.

[18] Pape, H.C.; Remmers, D.; Rice, J. et al. Appraisal of early evaluation of blunt chest trauma: Development of a standardized scoring system for initial clinical decision making. J. Trauma. 49:496-504. 2000. doi: 10.1097/00005373-200009000-00018.

[19] McLain, R.F. Functional outcomes after surgery for spinal fractures: Return to work and activity. Spine (Phila Pa 1976). 29:470-477. 2004. doi: 10.1097/01.BRS.0000092373.57039.FC.

[20] Rau, C.S. ; Wu, S.C. ; Kuo, P.J. et al.Polytrauma Defined by the New Berlin Definition: A Validation Test Based on Propensity-Score Matching Approach.Int J Environ Res Public Health. 14(9): 1045.2017. doi: 10.3390/ijerph14091045

[21] Fröhlich, M.; Driessen, A.; Böhmer, A.et al.Is the shock index based classification of hypovolemic shock applicable in multiple injured patients with severe traumatic brain injury?-an analysis of the TraumaRegister DGU(®).Scand J Trauma Resusc Emerg Med.24(1): p. 148.2016.

[22] Lui, C.T.; Wong, O.F.; Tsui, K.L. et al. Predictive model integrating dynamic parameters for massive blood transfusion in major trauma patients: The Dynamic MBT score. Am J Emerg Med. 36:1444-50.2018.

[23] Parks, J.K.; Elliott, A.C.; Gentilello, L.M. et al. Systemic hypotension is a late marker of shock after trauma: a validation study of Advanced Trauma Life Support principles in a large national sample. Am J Surg. 192:727-31. 2006.

[24] Siegel, J.H. The effect of associated injuries, blood loss, and oxygen debt on death and disability in blunt traumatic brain injury: the need for early physiologic predictors of severity. J Neurotrauma. 12:579-90. 1995.

[25] Rossaint, R.; Bouillon, B.; Cerny, V. et al. The European guideline on management of major bleeding and coagulopathy following trauma: fourth edition. Crit Care.20:100.stew. 2016.

[26] Stewart, R.M.; Brasel, K.; Henry, S. Shock. In: Stewart RM, Brasel K, Henry S., editors. Advanced trauma life support student course manual. 10th ed. Chicago, IL; American College of Surgeons. The Committee on Trauma. Chapter 3; p. 43-61.2018. 
[27] Varga, E.; Csonka, E.; Kószó, B. et al. Advanced Trauma Life Support (ATLS) in Hungary; The First 10 Years. Bull Emerg Trauma. 4:48-50.2016.

[28] Mutschler, M.; Paffrath, T.; Wölfl, C. et al. The ATLS(®) classification of hypovolaemic shock: a well established teaching tool on the edge? Injury.45:S35-8.2014.

[29] Kortbeek, J.B.; AlTurki, S.A.; Ali, J. et al. Advanced trauma life support, 8th edition, the evidence for change. J Trauma. 64:1638-50.2008.

[30] Mutschler, M.; Nienaber, U.; Brockamp, T. et al. A critical reappraisal of the ATLS classification of hypovolaemic shock: does it really reflect clinical reality? Resuscitation. 84:309-13. 2013.

[31] Mutschler, M.; Nienaber, U.; Brockamp, T. et al. Renaissance of base deficit for the initial assessment of trauma patients: a base deficit-based classification for hypovolemic shock developed on data from 16,305 patients derived from the TraumaRegister DGU ${ }^{\circledR}$. Crit Care. 17:R42.2013.

[32] Porter, J.M.; Ivatury, R.R. In search of the optimal end points of resuscitation in trauma patients: a review. J Trauma. 44:908-14.1988.

[33] Guerado, E.; Medina, A.; Mata, M. et al. Protocols for massive blood transfusion: when and why, and potential complications. Eur J Trauma Emerg Surg. 42:283-95.2016.

[34] Caputo, N.; Fraser, R.; Paliga, A. et al. Triage vital signs do not correlate with serum lactate or base deficit, and are less predictive of operative intervention in penetrating trauma patients: a prospective cohort study. Emerg Med J.30:546-50.2013.

[35] Dunne, J.R.; Tracy, J.K.; Scalea, T.M. et al. Napolitano LM. Lactate and base deficit in trauma: does alcohol or drug use impair their predictive accuracy? J Trauma. 58:95966.2005.

[36] Ibrahim, I.; Chor, W.P.; Chue, K.M. et al. Is arterial base deficit still a useful prognostic marker in trauma? A systematic review. Am J Emerg Med.34:626-35.2016.

[37] Lam, S.W.; Lingsma, H.F.; van Beeck, E.F. et al. Validation of a base deficit-based trauma prediction model and comparison with TRISS and ASCOT. Eur J Trauma Emerg Surg.42:627-33.2016.

[38] Raux, M.; Le Manach, Y.; Gauss, T. et al. Comparison of the Prognostic Significance of Initial Blood Lactate and Base Deficit in Trauma Patients. Anesthesiology. 126:522-33.2017.

[39] Dunham, M.P.; Sartorius, B.; Laing, G.L. et al. A comparison of base deficit and vital signs in the early assessment of patients with penetrating trauma in a high burden setting.Injury. 48:1972-77.2017.

[40] Herbert, H.K.; Dechert, T.A.; Wolfe, L. et al. Lactate in trauma: a poor predictor of mortality in the setting of alcohol ingestion. Am Surg. 77:1576-9.2011. 
[41] Gustafson, M.L.; Hollosi, S.; Chumbe, J.T. et al. The effect of ethanol on lactate and base deficit as predictors of morbidity and mortality in trauma. AmJ EmergMed.33:60713.2015 .

[42] Davis, J.W.; Kaups, K.L. Base deficit in the elderly: a marker of severe injury and death. J Trauma.45:873-7.1998.

[43] Roberts, I.;Shakur, H.; Coats, T. et al., The CRASH-2 trial: a randomised controlled trial and economic evaluation of the effects of tranexamic acid on death, vascular occlusive events and transfusion requirement in bleeding trauma patients.Health Technol Assess. 17(10): p. 1-79.2013.

[44] Karuppaiah, K. Mortality after Major Trauma - An Analysis of the Factors that Impact Trauma Survivorship between India and the United Kingdom.International journal of orthopaedics.6.2019.

[45] Shockley, L., et al., Emergency Trauma Care: Current Topics and Controversies Volume I. EB Medicine.2015.

[46] Harrop, J.S.; Rymarczuk, G.N.; Vaccaro, A.R.et al., Controversies in Spinal Trauma and Evolution of Care.Neurosurgery. 80(3s): p. S23-s32.2017.

[47] Lefering, R.; Ruchholtz, S.Trauma registries in Europe.European Journal of Trauma and Emergency Surgery. 38(1): p. 1-2.2012.

[48] Dewar, D.;Moore, F.A.; Moore, E.E.et al. Postinjury multiple organ failure.Injury.40(9): p. 912-8.2009.

[49] Alberer, M.; Malinowski, S.; Sanftenberg, L.et al., Notifiable infectious diseases in refugees and asylum seekers: experience from a major reception center in Munich, Germany.Infection.46(3): p. 375-383.2018.

[50] Edwards, A.;Di Bartolomeo, S.; Chieregato, A.et al., A comparison of European Trauma Registries. The first report from the EuroTARN Group. Resuscitation.75(2): p. 286-97.2007.

[51] Kernacki, K.A.; Goebel, D.J.; Poosch, M.S.et al., Early cytokine and chemokine gene expression during Pseudomonas aeruginosa corneal infection in mice.Infect Immun.66(1): p. 376-9. 1998.

[52] Bogner, V.; Kanz, K.G.; Kirchhoff, C.et al., Very early posttraumatic serum alterations are significantly associated to initial massive RBC substitution, injury severity, multiple organ failure and adverse clinical outcome in multiple injured patients. Eur J Med Res.14(7): p. 284-91.2009.

[53] Shakur, H.; Roberts, I.; Bautista, R. et al. Effects of tranexamic acid on death, vascular occlusive events, and blood transfusion in trauma patients with significant hemorrhage (CRASH-2): a randomised, placebo-controlled trial. Lancet.376:23-32.2010.

[54] Kutcher, M.E.; Kornblith, L.Z.; Narayan, R. et al. A paradigm shift in trauma 42 
resuscitation: evaluation of evolving massive transfusion practices. JAMA Surg.148:83440.2013.

[55] Hafeez, W. Resuscitation. In: Cunningham S, Crain E, Gershel J, editors. Clinical Manual of Emergency Pediatrics. Cambridge: Cambridge University. pp. 1-29.2010.

[56] Fleming, S.; Thompson, M.; Stevens, R. et al. Normal ranges of heart rate and respiratory rate in children from birth to 18 years: a systematic review of observational studies. Lancet.377:1011-18.2011.

[57] American College of Surgeons. Advanced Trauma Life Support. Available from: https://www.facs.org/quality\%20programs/trauma/atls

[58] Mofidi, M.; Hasani, A.; Kianmehr, N. Determining the accuracy of base deficit in diagnosis of intra-abdominal injury in patients with blunt abdominal trauma. Am J Emerg Med. 28:933-36.2010.

[59] Aukema, T.S.; Hietbrink, F.; Beenen, L.F. et al. Does thoracic injury impair the predictive value of base deficit in trauma patients? Injury.2010. https://doi.org/10.1016/j.injury.2010.04.003.

[60] Bonanno, F.G. Hemorrhagic shock: The "physiology approach". J Emerg Trauma Shock.5:285-95.2012.

[61] Abou-Khalil, B.; Scalea, T.M.; Trooskin, S.Z. et al. Hemodynamic responses to shock in young trauma patients: need for invasive monitoring. Crit Care Med.22:6339.1994.

[62] Guly, H.R.; Bouamra, O.; Little, R. et al. Testing the validity of the ATLS classification of hypovolaemic shock. Resuscitation.81:1142-7.2010.

[63] Brasel, K.J.; Guse, C.; Gentilello, L.M. et al. Heart rate: is it truly a vital sign? J Trauma. 62:812-7.2007.

[64] Loftus, T.J.; Efron, P.A.; Moldawer, L.L. et al. $\beta$-Blockade use for Traumatic Injuries and Immunomodulation: A Review of Proposed Mechanisms and Clinical Evidence. Shock.46:341-51.2016.

[65] Taniguchi, T.; Kurita, A.; Yamamoto, K. et al. Effects of carvedilol on mortality and inflammatory responses to severe hemorrhagic shock in rats. Shock. 32:272-5.2009.

[66] Cooke, W.H.; Salinas, J.; Convertino, V.A. et al. Heart rate variability and its association with mortality in prehospital trauma patients. JTrauma.60:363-70.2006.

[67] Little, R.A.; Kirkman, E.; Driscoll, P. et al. Preventable deaths after injury: why are the traditional 'vital' signs poor indicators of blood loss? J Accid Emerg Med. 12:1-14.1995.

[68] Keel, M; Trentz, O.Pathophysiology of polytrauma.Injury. 36(6): p. 691-709.2005.

[69] Hietbrink, F.; Koenderman, L.; Rijkers, Gt. et al., Trauma: the role of the innate 43 
immune system. World J Emerg Surg. 1: p. 15.2006.

[70] Bone, R.C.Immunologic dissonance: a continuing evolution in our understanding of the systemic inflammatory response syndrome (SIRS) and the multiple organ dysfunction syndrome (MODS).Ann Intern Med.125(8): p. 680-7.1996.

[71] Wang, M.;Wang, J.; Wang, T.et al., Thrombocytopenia as a predictor of severe acute kidney injury in patients with Hantaan virus infections.PLoS One. 8(1): p. e53236.2013.

[72] Le, R.J.; Larsen, C.M.; Fenstad, E.Ret al., Thrombocytopenia independently predicts death in idiopathic PAH.Heart Lung.48(1): p. 34-38.2019.

[73] Schefold, J.C.;Lainscak, M.; Hodoscek, L.M.et al. Single baseline serum creatinine measurements predict mortality in critically ill patients hospitalized for acute heart failure. ESC Heart Fail.2(4): p. 122-128.2015.

[74] Nouér, S.A.; Nucci, M.; Kumar, N.Set al., Baseline platelet count and creatinine clearance rate predict the outcome of neutropenia-related invasive aspergillosis. Clin Infect Dis.54(12): p. e173-83.2012.

[75] Kertai, M.D.; Yu, C.Platelet Counts, Acute Kidney Injury, and Mortality after Coronary Artery Bypass Grafting Surgery.Anesthesiology.124(2): p. 339-52.2016.

[76] Salim, A.; Hadjizacharia, P.; DuBose, J.et al., What is the significance of thrombocytosis in patients with trauma?J Trauma.66(5): p. 1349-54.2009.

[77] Valade, N.; Decailliot, F.; Rébufat, Y. et al., Thrombocytosis after trauma: incidence, aetiology, and clinical significance.Br J Anaesth.94(1): p. 18-23.2005.

[78] Nwomeh, B.C.; Lowell, W.; Kable, R. et al.History and development of trauma registry: lessons from developed to developing countries. World J Emerg Surg. 1:32.2006.

[79] Gliklich, R.E.; Dreyer, N.A.; Leavy, MB.; eds. Registries for Evaluating Patient Outcomes:A User's Guide. 3rd ed. Rockville (MD): Agency for Healthcare Research and Quality (US);2014.

\section{ANNEX}




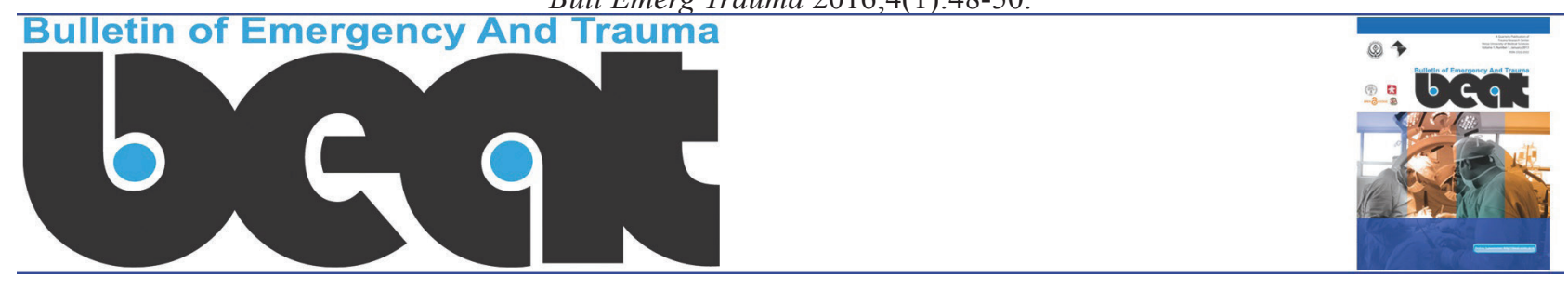

\title{
Advanced Trauma Life Support (ATLS) in Hungary; The First 10 Years
}

\author{
Endre Varga ${ }^{1,2 *}$, Endre Csonka1,2, Balázs Kószó ${ }^{1,2}$, Zoltán Petôt $^{2,3}$, Zsuzsanna Ágoston ${ }^{2,4}$, Erika Gyura $^{2,4}$, Gábor \\ Nardai $^{2,5}$, Kristóf Boa ${ }^{1}$, Gábor Süveges ${ }^{1,2}$
}

\author{
${ }^{1}$ Department of Traumatology, University of Szeged, Szeged, Hungary \\ ${ }^{2} A T L S$ Hungary \\ ${ }^{3}$ Emergency Department, University of Szeged, Szeged, Hungary \\ ${ }^{4}$ Department of Anesthesiology and Intensive Therapy, University of Szeged, Szeged, Hungary \\ ${ }^{5}$ Péterfy Sándor str. Hospital and Trauma Center, Budapest, Hungary
}

*Corresponding author: Endre Varga
Address: Department of Traumatology, University of Szeged, Szeged, Hungary,
H-6725, Szeged, Semmelweis u.6.
e-mail: office.trauma@med.u-szeged.hu

\section{ABSTRACT}

\begin{abstract}
Advanced Trauma Life Support (ATLS) programs are recognized as the standard educational trauma program worldwide. Data suggest that ATLS has a positive impact on the value of trauma care. The ATLS Hungary program has been started in 2005, celebrating its 10 -year anniversary this year. In the present brief communication a brief overview is provided on the program. Student evaluation and statistical data about the participants were collected throughout the 10-year history of the Hungarian program.Student evaluation shows a high level of satisfaction amongst the participating doctors. Most participants are working in higher level centers. The Hungarian program shows good quality according to the participants. Establishing at least one new center is crucial to be able to provide the course for every professional interested in it or required to take it.
\end{abstract}

Keywords: Advanced Trauma life support; ATLS; Trauma; Training; Hungary.

Please cite this paper as:

Varga E, Csonka E, Kószó B, Pető Z, Ágoston Z, Gyura E, Nardai G, Boa K, Süveges G. Advanced Trauma Life Support (ATLS) in Hungary; The First 10 Years. Bull Emerg Trauma. 2016;4(1):48-50.

$\mathrm{T}$ he history of ATLS is well known to have started with the famous Nebraska Experience of an orthopedic surgeon, Dr. James Styner'sinvolvement in a tragicfamily plane crash in rural Nebraska in 1976. Dr. Styner's patient experience of inadequate and inconsistent trauma care has facilitated the development of an educational program concerning trauma care in 1978, having been quickly accepted by the American College of Surgeons (ACS) [1].
The following decades brought a wonderful dissemination of the idea across the globe, as ATLS has been taught in 63 countries worldwide as of 2012 [1]. The intensive ATLS course includes the teaching of systematic approach to trauma care by means of simulated scenarios, practical skills teaching, lectures, and discussions, assessment including both skills examination and MCQ testing. The student course manual is being revised every 4 years to keep 
the material up-to-date.

The advantages of having a systematic approach to trauma seem straightforward, however, it is quite hard to measure the impact of it on the quality of care. Mohammad et al. have performed a systematic review of the available literature about the impact of ATLS both educationally and in terms of quality of care. They have concluded that there is strong evidence supporting the educational aspects of the positive impact of ATLS, however, its effect on mortality needs to be further investigated [2]. The 2014 update of the publication of the Cochrane Database of Systematic Reviews, concerning the same topic have had a similar conclusion. They have also stated that high-quality, controlled investigation of the systemic effect of ATLS is very challenging [3]. However, there are some good quality investigations in the topic. Hashmi et al. have found that patients were 4.9 times less likely to die and 2.6 times less likely to have complications after the implementation of an ATLS-based trauma system, compared to the period before [4]. Hedges et al. have investigated the effect of certain ATLS-based interventions on survival of high-risk patients in a rural hospital. They have found that ATLS-based administration of blood products and patient transfer to a higher level center improved survival, underlining the positive impact of ATLS on quality of care [5]. Medical staff undergone ATLS training have also been shown to be more effective in simulated trauma scenarios by Williams et al., [6].

The history of ATLS in Hungary started in 1993 with the first author of this present article having the chance to see the concept in work in Canada. This experience led to the establishment of a workgroup of four Hungarian trauma surgeons at the University of Szeged (ZsoltBalogh, JánosTomka, GáborSüveges, and EndreVarga being involved). This was followed by years of hard work to make it possible to start the Hungarian ATLS program. The ACS agreed on starting the Hungarian program in 1999, and after establishing the financial and infrastructural background, the first course was held in Szeged in2005, just a couple of years later than the first German one. A big strength of our course is the opportunity to perform procedures in the state-of-the-art animal lab of the University of Szeged. ATLS Hungary was also a founding member of ATLS Europe and is an active member of it ever since. As of 2015, Hungary is still one of the only three countries from Eastern Europe to have an ATLS program, the other two countries being Lithuania and Slovenia [7]. The $20^{\text {th }}$ Hungarian course is going to be held in December, 2015. The instructors' program is also successfully running with about $25 \%$ of the participants showing instructor potential and 3 instructor courses held throughout the years.

Szeged is still the only ATLS center in Hungary, organizing 2 courses every year for 16 participants a course. Since 2013, successful completion of an ATLS course is a prerequisite for the Hungarian state board examination in orthopedics \& trauma surgery. Also, as the Hungarian emergency system is shifting to establishing central Emergency Departments replacing the old, separated emergency system for the different specialties, more-and-more residents are going to start in the field of emergency medicine, with the possibility of the ATLS course becoming a prerequisite for the board examination in emergency medicine as well. These two facts indicate that the interest in the course is going to significantly rise in the near future. The Szeged center with 2 courses a year is not going to be able to deal with this load, thus, opening 2 new course sites in other Hungarian trauma centers is compelling.

Investigating the impact of ATLS on the quality of Hungarian trauma care would be very challenging, however, after 19 successful courses and 305 participants, there are some interesting data about the Hungarian ATLS program.

It is very important to make the idea and concept of the training spread in the Hungarian trauma system. As nearly half of the participants were under 30, and as completion of an ATLS course is now a prerequisite for obtaining an orthopedics \& trauma certification, we can hope that the front line of the near future of the Hungarian trauma system will bear the skills and foundations required for a stateof-the-art approach. Nearly $50 \%$ of the participants came from either a university hospital or the National Institute of Traumatology, thus representing the high levels of Hungarian trauma care. We hope to further spread the concept amongst the lower level centers. Over $80 \%$ of the participants were working in the specialty fields of orthopedics \& trauma, traumatology, anesthesiology \& intensive therapy, and emergency medicine, showing the major specialties participating in trauma care in the Hungarian trauma settings.

An educational activity is very accurately judged by the satisfaction of the participants, thus it is very important for every ATLS center. This feedback can assure that the quality of the course remains on the desired level. All of the 305 participants responded positive to the question 'Have you learned new and useful information?'. It shows that a structured educational strategy can be useful to every participant.Similarly, all of the participants responded positive to the question 'Does it worth the time spent on it?'As high as $97 \%$ of the participants thought that the course did worth the course fee. The skills practices and simulated scenarios are very important parts of the ATLS course, but it is also very important to keep the lectures on a high level of quality. The lectures are evaluated year-to-year to keep that high level. If scores from all years are evaluated at once, none of the lectures get an average grade below 4.6 on a scale of 5 (Figure 1.).

Participants' failure is also a very important aspect 


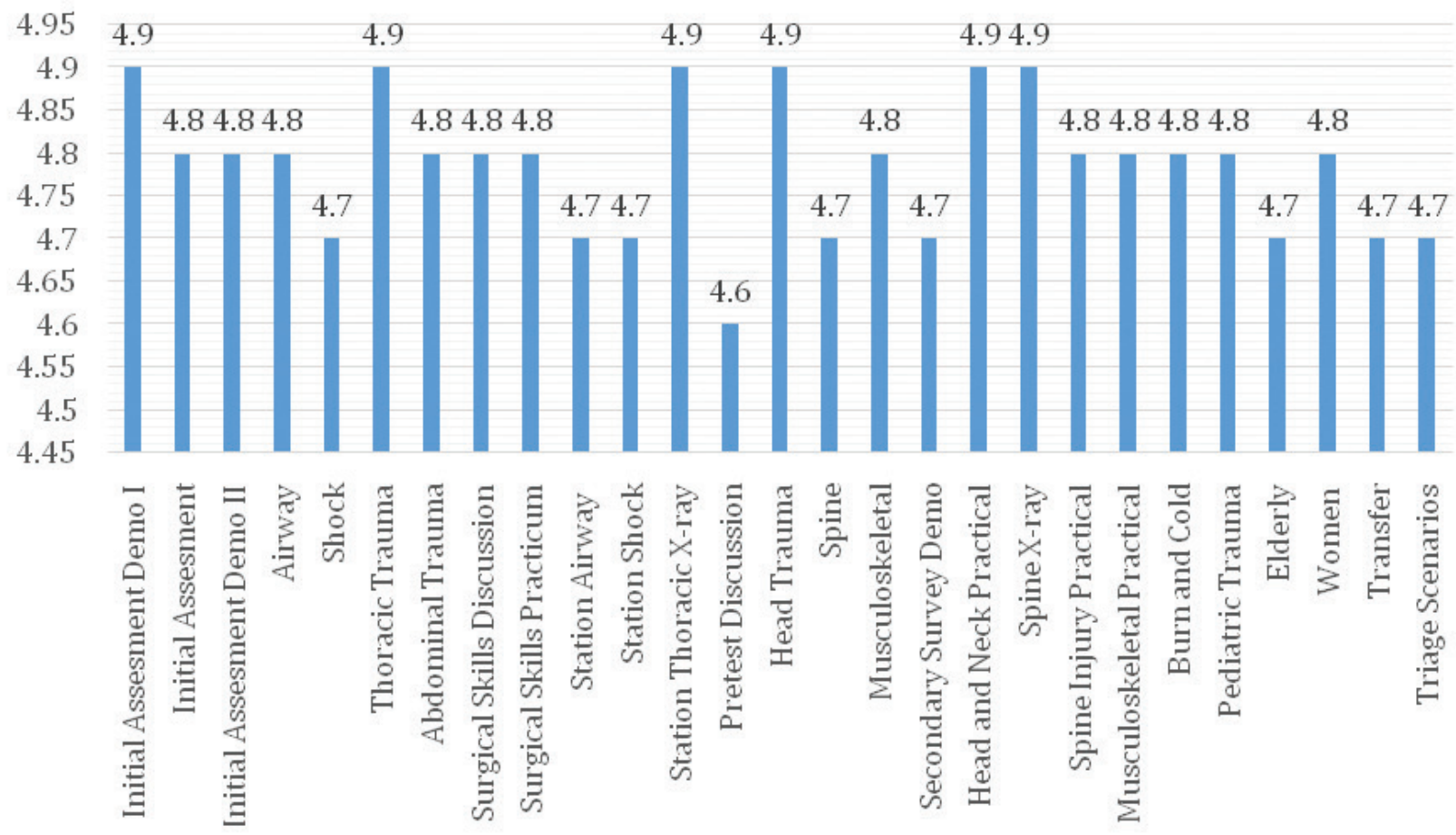

Fig. 1. Average grading of the lectures by the participants.

of a medical educational course. Only a bit over $3 \%$ of the participants failed to pass, and less than $10 \%$ had to retake either the MCQ or the practice examination. These points to the fact that until recently, taking the course was not obligatory, thus all participants were motivated. It is going to be interesting to see if the failure rate changes with the course becoming a prerequisite for the orthopedics \& trauma board examination, and possibly for the emergency medicine board examination as well.

As skills-centered, practice-based, structured education gains more and more territory in both undergraduate and graduate medical education, we hope that we can build on the success of the Hungarian ATLS program and that these efforts lead to further improvement of the Hungarian trauma system.

\section{Acknowledgements}

Hereby, we would like to thank our colleagues Edina Várkonyi and Nikolett Juhász for their hard work and dedication towards the success of the Hungarian program. We would also like to thank Professor Mihály Boros and József Kaszaki from the Institue of Surgical Research, University of Szeged for their huge contribution to the skills part of the program by providing their infrastructure and knowledge concerning animal lab procedures.

Conflict of Interest: None declared.

\section{References}

1. American College of Surgeons. Advanced trauma life support for doctors. Student course manual. $9^{\text {th }}$ ed. Chicago, Illinois: American College of Surgeons; 2012.

2. Mohammad A, Branicki F, Abu-Zidan FM. Educational and clinical impact of Advanced Trauma Life Support (ATLS) courses: a systematic review. World J Surg. 2014;38:322-9.

3. Jayaraman S, Sethi D, Chinnock P, Wong R. Advanced trauma life support training for hospital staff.
Cochrane Database Syst Rev. 2014;8:CD004173.

4. Hashmi ZG, Haider AH, Zafar SN, Kisat M, Moosa A, Siddiqui F, et al. Hospital-based trauma quality improvement initiatives: first step toward improving trauma outcomes in the developing world. $J$ Trauma Acute Care Surg. 2013;75(1):60-8; discussion 8 .

5. Hedges JR, Adams AL, Gunnels MD. ATLS practices and survival at rural level III trauma hospitals, 1995-1999. Prehosp Emerg Care. 2002;6(3):299-305.

6. Williams MJ, Lockey AS, Culshaw MC. Improved trauma management with advanced trauma life support (ATLS) training. J Accid Emerg Med. 1997;14(2):81-3.

7. In: American College of Surgoens. Advanced Trauma Life Support. Available from: https://www.facs. org/quality $\% 20$ programs/trauma/atls. 


\section{Research article}

Comparison of the previous and current trauma-related shock classifications $-A$ retrospective cohort study from a level I trauma centre

Péter Jávor ${ }^{1}$, Endre Csonka ${ }^{1}$, Edina Butt ${ }^{1}$, Ferenc Rárosi $^{2}$, Barna Babik ${ }^{3}$, László Török ${ }^{1}$, Endre Varga $^{1}$, Petra Hartmann ${ }^{4}$

${ }^{1}$ Department of Traumatology, University of Szeged, Szeged, Hungary

${ }^{2}$ Department of Medical Physics and Informatics, University of Szeged, Szeged, Hungary

${ }^{3}$ Department of Anaesthesiology and Intensive Therapy, University of Szeged, Szeged, Hungary

${ }^{4}$ Institute of Surgical Research, University of Szeged, Szeged, Hungary

Short Title: Comparison of trauma-related shock classifications

\section{Corresponding author:}

Petra Hartmann M.D., Ph.D. ${ }^{4}$

Pulz utca 1., Szeged, 6723 - Hungary

Tel: +(36-62) 545-103; Fax: +(36-62) 545-743;

E-mail: hartmann.petra@med.u-szeged.hu

Number of Tables: 5

Number of Figures: 3

Word count: 3394 (including abstract and body text)

Keywords: "multiple trauma"; "shock, hemorrhagic"; "vital signs"; "heart rate"; "ATLS" 


\begin{abstract}
Purpose: The aim was to examine the predictive value of hypovolemic shock classification currently accepted by the Advanced Trauma Life Support (ATLS) program over the previous one, which used only vital signs (VS) for patient allocation. Primary outcome was 30-day mortality, as secondary outcome heart rate (HR), systolic blood pressure (SBP), Glasgow Coma Scale (GCS) and base deficit (BD) data were compared and investigated in terms of mortality prediction.
\end{abstract}

Methods: Retrospective analysis at a level I trauma centre between 2014 and 2019. Adult patients treated by trauma teams were allocated into severity classes (I-IV) based on the criteria of the current and previous ATLS classifications, respectively. The prognostic values for the classifications were determined with Fisher's exact test and Chi-square test for independence; and compared with two-proportion Z-test. The individual variables were analyzed with receiver operating characteristic (ROC) analyses.

Results: A total of 156 patients met the inclusion criteria. Mortality was effectively predicted by both classifications, there was no statistically significant difference between the predictive performances. According to ROC-analyses, GCS, BD and SBP had significant prognostic values while HR change was ineffective in this regard.

Conclusions: The currently used ATLS shock classification does not appear to be superior to the VS-based previous classification. GCS, BD and SBP are useful parameters to predict the prognosis. Changes in HR do not reflect the clinical course accurately, thus further studies will be needed to determine the value of this parameter in trauma-associated hypovolemichemorrhagic shock conditions. 


\section{Introduction}

\section{$1.1 \quad$ Background}

Blood loss is one of the leading causes of death, but the most frequent single cause is still traumatic brain injury (TBI). [1] [2]. Hypovolemic shock is the second main cause of mortality in trauma patients [3] [4], and the outcome can be improved significantly through early recognition, intravenous fluid resuscitation and blood transfusions [5]. Currently, the Advanced Trauma Life Support (ATLS) program provides well-established guidances for early assessment and initial management of major trauma and suspected hemorrhage by allocating the patients into severity classes I-IV, respectively [6] [7]. Until recently, the earlier guidance proposed the use of vital signs (VS) only, including heart rate (HR), systolic blood pressure (SBP) and Glasgow Coma Scale (GCS) to aid the recognition of shock and estimate blood loss [8] [9]. However, the predictive value of VS-based classification has been questioned and in 2013, the analysis of the Trauma Register DGU ${ }^{\circledR}$ (Deutsche Gesellschaft für Unfallchirurgie) indicated that the VS-based classification does not reflect the clinical condition accurately. Therefore, the use of base deficit (BD) as a sole parameter in the classification has been recommended [10] [11].

$\mathrm{BD}$ is a metabolic marker reflecting the acid-base status of the patients and commonly used to assess hemorrhage and its consequences [12-14]. Several studies have documented its ability to predict mortality and post-injury transfusion requirements and highlighted its role in the early assessment of injury severity of trauma patients [11] [15-19]. Therefore, the latest ATLS recommendation expanded the assessment criteria with the $\mathrm{BD}$ value [6]. However, the specificity of BD for hypovolemia prediction is still questionable, since not only metabolic acidosis, but other factors such crystalloids (lactated Ringer or saline) can also elevate BD [18]. Furthermore, alcohol or drugs, commonly seen in trauma patients, may also diminish its 
predictive accuracy [20] [21]. Besides, it has been demonstrated that patients over 55 years may have significant injuries and mortality risk without manifest BD alterations [22].

\subsection{Objectives}

Based on this backround our primary goal was to examine the predictive power of the currently accepted ATLS classification of hypovolemic shock to confirm or refute the superiority of VS+BD detection over the previously used (VS only) protocol. For this purpose, we conducted a retrospective cohort analysis at a level I trauma centre to compare the VS+BD and VS classifications in terms of their ability to predict mortality. Our secondary goal was to determine the parameters with strong prognostic possibilities in the early assessment phases of the injured. Therefore, the predictive values of HR, SBP, GCS and BD were also calculated. 


\section{Materials and Methods}

\subsection{Study design}

The present study is a retrospective cohort analysis at a single, level I trauma centre located in an urban area. The level I qualification is based on national standards regarding the kinds of resources available and the number of patients admitted yearly. The designation criteria correspond to United States of America standards.

\subsection{Data collection}

In the past decades, there were several important changes in emergency trauma guidelines, such as the paradigm shift in fluid resuscitation and the introduction of tranexamic acid [23] [24]. Taking this into account, we decided to analyze data only from the past 5 years, the data were collected between 11 July 2014 and 11 September 2019 from the electronic database (MedSolution) at the University of Szeged. The protocols of emergency trauma care including massive transfusion protocols at the institution have been in complience with the principles of ATLS during the whole study period.

\subsection{Inclusion criteria}

The inclusion criteria consisted of trauma team activation, transport directly from scene, age of 16 years or greater, a detailed documentation including Abbreviated Injury Scale (AIS), Injury Severity Score (ISS), the accurate mechanism of injury and a complete dataset for HR, SBP, GCS and BD recorded at presentation. Regarding physiological variables, the values of the first in-hospital measurements were included and reported. The activation of the trauma team is based on anatomical and physiological criteria and the mechanism of injury. High-energy trauma is characterized by high amount of kinetic energy inducing severe tissue damage; and typically sustained by road traffic accidents, crush or blust injuries, and falling from heights. The clinical handover between paramedics and emergency department staff follows the MIST and AMPLE templates (MIST: M - Mechanism of Injury; I - Injuries Sustained; S - Signs; T 
- Treatment and Trends in the Vital Signs. AMPLE: A - Allergies; M - Medications; P - Past Medical History; L - Last Ate; E - Events). The age limit of 16 years was selected according to the fact that normal values of HR and SBP by adolescents above that age do not differ largely from the normal values by adults [25] [26].

The recorded variables included the mechanism of injury, the International Statistical Classification of Diseases and Related Health Problems (ICD) codes, vital parameters (HR, SBP and GCS) measured by the trauma team at presentation, BD and 30-day survival. Although prehospital treatment might have influenced the parameters, paramedics use a unified protocol including guidance regarding the prehospital fluid resuscitation, administration of vasopressors and opioid analgesics also. Vasopressors have a controversial role in the management of the severely injured [27] [28]. They are administered mainly to maintain cerebral perfusion pressure (CPP) in cases of severe TBI and concomitant hemorrhage, where increasing intracranial pressure (ICP) and decreasing mean arterial pressure (MAP) work simultaneosly against CPP. Another indication for using vasopressors is the failure of maintaining blood pressure with fluid resuscitation only [28] [29].

When patients were discharged from the hospital earlier than 30 days, the follow-up was completed as a part of outpatient care. Patients who received cardiopulmonal resuscitation on scene or primary survey in another institute were excluded. Additionally, imprecise documentation and missing variables also entailed exclusion.

\subsection{Patient groups}

The ATLS does not explicitly declare whether the worst parameter or a combination of all the parameters should determine the severity class of the patient. Most trauma patients cannot be allocated correctly to the four ATLS severity classes (I-IV) when a combination of vital parameters is assessed [8] [10]. Therefore, the participants' allocation was based on their worst parameter within the VS and VS+BD criteria. Since the current ATLS shock classification does 
not describe exact values for HR, SBP and GCS, we adopted HR values from the previous ATLS classification and SBP and GCS values from the study of Dunham et al. to make the criteria objective and transparent [19]. (Table 1)

Table 1. Simplified shock classification using absolute values

\subsection{Outcomes}

As a primary outcome, we compared the VS and VS+BD classifications with respect to 30-day mortality, taking the close relationship of the severity of bleeding to the risk for adverse outcomes into consideration [8] [11] [17] [19] [30].

As a secondary goal, we studied the prognostic potential for the individual parameters (HR, SBP, GCS and BD, respectively) to be able to determine the strongest and weakest predictive factors in the initial assessment.

\subsection{Statistical analysis}

Continuous data were expressed as mean \pm standard deviation. Categorical data were expressed as frequency or relative frequency (percentages). Chi-square tests for independence were performed to test the reationship between VS+BD classification result and outcome of mortality. The assumption of chi-square test for independence was slightly violated in the crosstabulation of VS classification result and outcome of mortality, therefore Fisher's exact test was used to test the relationship between VS classification result and outcome of mortality. Two-proportion Z-test was performed to compare the predictive power of the VS and VS+BD classifications. Binary logistic regression was applied for further analysis between VS+BD classification result (groups 1, 2 vs groups 3,4) and outcome of mortality, odds-ratio and 95\% confidence interval for odds-ratio were calculated.

The predictive performance of individual variables was assessed using receiver operating characteristic (ROC) analysis. Area under ROC curve was calculated for each individual 
variable (candidate predictors: GCS, HR, SBP, BD). Hypothesis tests for AUC ROC were performed and $95 \%$ confidence bounds for AUC ROC were calculated with nonparametric method. A P-value $P<0.05$ was considered to be statistically significant. All data were analyzed by using statistical software IBM SPSS 25.0 (IBM Corporation, Chicago, IL, USA). 


\section{Results}

\subsection{Patient population and demographics}

A total of 684 patients were admitted to our institution with activation of the trauma team. Ultimately, 156 participants met our inclusion criteria. The flowchart for patient enrollment is presented in Figure 1.

Fig. 1. Study flowchart

The mean age of the participants was $49.4 \pm 20.7$ years, and only $26.7 \%$ of the patients were female. The most common mechanisms of injury were road traffic accidents (56.4\%) and falls (29.5\%). The most affected body regions were the head and neck (74.4\%), thorax (53.9\%), and extremities $(48.1 \%)$. Due to the fact, that most patients suffered a high energy trauma, multiple body regions were involved in several cases. The characteristics of the patient population are shown in Table 2, the distribution of injury mechanisms, affected body regions and clinical outcomes are demonstrated in Table 3.

Table 2. Patient characteristics

Table 3. Severity and mechanisms of injury, affected body regions, outcomes

\subsection{Results of statistical analyses}

According to VS, $31.4 \%$ of the patients were assigned to class I, $6.4 \%$ to class II, $13.5 \%$ to class III and $48.7 \%$ to class IV. Based on VS+BD criteria, $16.0 \%$ of the patients were reallocated to a higher severity class; however, this change affected mostly the low-risk classes (I and II). 34 patients died within the first 30 days, resulting in a mortality rate of $21.8 \%$. The distribution of patients and mortality among the classes are shown in Figure 2.

Fig. 2. Distribution of patients (A) and mortality (B) among the severity classes based on VS and VS+BD 
Both the VS and VS+BD classifications showed a strong relation to mortality (chi-square and Fisher's exact tests $P_{\mathrm{VS}}=0.0001$ vs. $P_{\mathrm{VS}+\mathrm{BD}}=0.000009$, respectively). These results are shown in Tables 4 and 5. According to the two-proportion Z-test, there was no significant difference in their predictive performance of mortality $(P=0.9808)$.

Table 4. Fisher's exact test of VS and mortality

Table 5. Chi-square test of VS+BD and mortality

Through a separate analysis of HR, SBP, GCS and BD, we found that GCS has the highest prognostic power $\left(\mathrm{AUC}_{\mathrm{GCS}}=0.799, P<0.001 ; \mathrm{CI}[0.722,0.875]\right)$. Derangements in BD and SBP were significant but weak predictors of mortality $\left(\mathrm{AUC}_{\mathrm{BD}}=0.683, P=0.001\right.$, CI $[0.576,0.790]$; $\left.\mathrm{AUC}_{\mathrm{SBP}}=0.633, P=0.018, \mathrm{CI}[0.521,0.744]\right) . \mathrm{HR}$ was found ineffective in prognosis $\left(\mathrm{AUC}_{\mathrm{HR}}=\right.$ 0.595, $\mathrm{P}=0.090, \mathrm{CI}[0.480,0.710])$. The results of the ROC analysis with the ROC curves for the variables are shown in Figure 3.

Fig. 3. ROC analysis of the individual variables

The binary logistic regression analysis confirmed that the risk for mortality increases massively in the higher severity classes (III and IV) as compared to the less severe ones (I and II). The results of the analysis are demonstrated in Supplementary Table 1. 


\section{Discussion}

\subsection{Interpretation of results}

This study was designed to investigate the previous, VS-based and the current ATLS classifications and the prognostic power of the parameters. Both classifications were highly effective in predicting mortality, with no significant difference between their prognostic values. Therefore, the superiority of VS+BD over the VS classification could not be confirmed.

Some other findings are also noteworthy, as we have demonstrated that more than $90 \%$ of all deaths were distributed in classes III and IV. This data underlines the importance of the threshold between classes II and III, where the first derangements in SBP, respiratory rate and urinary output usually occur [6]. According to other studies, the threshold BD value between these two classes $(6 \mathrm{mmol} / \mathrm{L})$ shows a notable predictive potential for mortality and transfusion requirements post-injury [16] [22] [31] [32]. $6 \mathrm{mmol} / \mathrm{L}$ is also the threshold from where the administration of blood products is recommended by ATLS [6]. The therapeutic and prognostic relevance of this point questions the reasonability of dividing trauma patients into four different severity groups. Additionally, due to the need for rapid decisions in the emergency trauma setting, the complexity of the ATLS shock classification has already received criticism before its extension with the BD [33]. Based on our study, combining the less severe classes (I and II) and the severe classes (III and IV) could be a legitimate option to increase the practicality of the classification. A pragmatic scale for the assessment of hemorrhage in decision making and triage may reduce the time from patient arrival to massive transfusion protocol activation and involvement of the right specialist (e.g.: abdominal surgeon, thoracic surgeon, etc.). Of course, a simplified classification like this should always be evaluated together with the adjuncts of the primary survey (e.g.: extended Focused Assessment with Sonography for Trauma (eFAST) and pelvic X-ray). During the secondary survey, trauma patients could undergo a comprehensive, detailed assessment to estimate the extent of optimal fluid replacement. 
It is important to note that we investigated ATLS shock classifications as early prognostic tools in the primary survey, where the exact set of injuries is unknown. We took it into consideration that the adequate evaluation of TBIs can only be accomplished with computer tomography, after the primary survey. Therefore, the 23 patients who sustained isolated head injuries were not excluded from our study.

As a secondary outcome, the predictive values of the individual variables were evaluated. GCS, BD and SBP showed a significant predictive performance. While GCS displayed a relatively strong relation to the outcome, the relation was weak for BD and SBP. In our study, BD and SBP alone did not appear to have a sufficiently high prognostic potential to be the foundation for the early assessment. According to other studies, SBP is considered to have a poor reliability in the early assessment, since hypotension usually does not occur until the degree of shock is profound [3] [34]. Despite of its strong relation to mortality, GCS can be affected by several factors besides hypotension, such as traumatic brain injury or alcohol intoxication [35].

Of note, HR did not have a significant relation to mortality in our study. Numerous factors such as anxiety, pain and medication can lead to elevated HR, making the specificity of tachycardia for hypotension questionable [35] [36]. Increased HR may also be masked via beta blockers [37] [38] (particularly in combination with $\mathrm{Ca}^{2+}$-channel inhibitors and ACE inhibitors) or physiological bradycardia [39]. Multiple studies pointed out that HR tends to demonstrate a biphasic response to bleeding since the patients develop bradycardia as blood loss becomes profound after initial tachycardia [34] [40] [41]. In our study, the predictive values of the individual variables showed the following ranking: $\mathrm{GCS}>\mathrm{BD}>\mathrm{SBP}>\mathrm{HR}$. The relevant differences between the variables suggest that weighing them and using their combination to allocate trauma patients could potentially increase the accuracy and specificity of the classification for hemorrhage. However, further research with larger sample size is required to elaborate such modifications. 


\subsection{Limitations}

The retrospective nature can be considered as a limitation in itself. Although our cohort analysis with the given sample size only has limited value as a validation study, it provides original research information in a controversial topic and highlights potential areas of improvement for an assessment tool that is mistrusted by several clinicians [8].

With regard to GCS upon admission, the concern emerges whether prehospital intubation had a major influence on patient allocation. In accordance with the paramedics protocol, on-scene intubation is indicated in case of GCS $<8$, which already entails the allocation into class IV according to the criteria of shock classification used in our study. Consequently, the distortional effect of prehospital intubation on our results is not likely.

The use of vasopressors occurred mostly in classes III-IV, thus having less influence on our results. The notable amount of excluded patients and our unability to include respiratory rate and urinary output in the analysis are due to the lack of comprehensive documentation.

\subsection{Conclusions}

Despite the significant relationship between BD and mortality, the previous and current ATLS classifications yielded nearly equivalent predictive performances, thereby rendering the added value of $\mathrm{BD}$ to the classification questionable. Undoubtedly, post-injury vital sign values are continuously changing during trauma care and individual reactions can vary greatly. Despite these facts, trends may appear in the derangements of physiological variables. In this study, the capability of individual variables to predict mortality followed the GCS $>B D>S B P>H R$ ranking. The role of HR in the early assessment of trauma patients may worth reconsideration in further studies since it does not seem to reflect the clinical condition accurately. Although the ATLS shock classification is not necessarily a pragmatic scale, it has become taught in more than 60 countries, making an impact on the approach of young clinicians to the initial management of 
the severely injured. Taking these considerations is into account, striving for the further targeted clicinal investigations and the development of the classification may be advantageous. 


\section{Declarations}

\subsection{Funding Sources}

The study was funded by National Research Development and Innovation Office grant NKFI K120232. It was further funded by Economic Development and Innovation Operative Programme Grants (GINOP-2.3.2-15-2016-00015) and Human Resource Development Operational Programme Grants (EFOP- 3.6.2-16-2017-00006).

\subsection{Conflict of Interests Statement}

The authors declare that they have no competing interests.

\subsection{Statement of Ethics}

The study was conducted in accordance with the Declaration of Helsinki and has been approved by the local medical ethics committee at the University of Szeged (Regional Human Biomedical Research Ethics Committee, University of Szeged. Chairman: Prof. Dr. Tibor Wittmann) under reference number 182/2019-SZTE. Given the retrospective nature of our study, no interventions have been performed. Upon admission, patients (or their relatives or guardians) signed a general informed consent including the permission to use their scientific information (except from personal data) for research purposes. The consent is available from: https://uszeged.hu/szakk/v/adatvedelem. The present record does not include personal data, photographs or other material that might identify the participants of our research. Personal data were not given out and will not be given out without the consent of our patients.

\subsection{Availability of data and materials}

The datasets used and analysed during the current study is available from the corresponding author on reasonable request.

\subsection{Authors' contributions}


PJ: preparation of the draft of the manuscript, formatting the manuscript, substantial contribution in study design, data extraction; ECs: expert in the field of traumatology, validation of data extraction, interpretation of data; EB: data extraction, preparation of the standardized data collection sheet; LT: expert in the field of traumatology, provided revisions to the scientific content of the manuscript; FR: statistical analyses; BB: expert in the field of anesthesiology and intensive therapy, provided revisions to the scientific content of the manuscript; EV: expert in the field of traumatology, provided revisions to the scientific content of the manuscript; $\mathrm{PH}$ : study design, study coordination, preparation of the manuscript, stylistic revision of the manuscript, provided revisions to the scientific content of the manuscript.

Hereby, all authors certify that they have participated sufficiently in the work to take public responsibility for the content.

\subsection{Acknowledgement}

The authors are thankful for the critical remarks of Mihály Boros during planning the study design and preparation of the manuscript. 


\section{References}

1 Frohlich M, Driessen A, Böhmer A, Nienaber U, Igressa A, Probst C et al. Is the shock index based classification of hypovolemic shock applicable in multiple injured patients with severe traumatic brain injury?-an analysis of the TraumaRegister DGU ${ }^{\circledR}$. Scand J Trauma Resusc Emerg Med. 2016;24:148.

2 Lui CT, Wong OF, Tsui KL, Kam CW, Li SM, Cheng M et al. Predictive model integrating dynamic parameters for massive blood transfusion in major trauma patients: The Dynamic MBT score. Am J Emerg Med. 2018;36:1444-50.

3 Parks JK, Elliott AC, Gentilello LM, Shafi S. Systemic hypotension is a late marker of shock after trauma: a validation study of Advanced Trauma Life Support principles in a large national sample. Am J Surg. 2006;192:727-31.

4 Siegel JH. The effect of associated injuries, blood loss, and oxygen debt on death and disability in blunt traumatic brain injury: the need for early physiologic predictors of severity. J Neurotrauma. 1995;12:579-90.

5 Rossaint R, Bouillon B, Cerny V, Coats TJ, Duranteau J, Fernández-Mondéjar E et al. The European guideline on management of major bleeding and coagulopathy following trauma: fourth edition. Crit Care. 2016;20:100.

6 Stewart RM, Brasel K, Henry S. Shock. In: Stewart RM, Brasel K, Henry S., editors. Advanced trauma life support student course manual. 10th ed. Chicago, IL; American College of Surgeons, The Committee on Trauma; 2018. Chapter 3; p. 43-61.

7 Varga E, Csonka E, Kószó B, Pető Z, Ágoston Zs, Gyura E et al. Advanced Trauma Life Support (ATLS) in Hungary; The First 10 Years. Bull Emerg Trauma. 2016;4:48-50. 
8 Mutschler M, Paffrath T, Wölfl C, Probst C, Nienaber U, Schipper IB et al. The ATLS(®) classification of hypovolaemic shock: a well established teaching tool on the edge? Injury. 2014;45:S35-8.

9 Kortbeek JB, Al Turki SA, Ali J, Antoine JA, Bouillon B, Brasel K et al. Advanced trauma life support, 8th edition, the evidence for change. J Trauma. 2008;64:1638-50.

10 Mutschler M, Nienaber U, Brockamp T, Wafaisade A, Wyen H, Peiniger S et al. A critical reappraisal of the ATLS classification of hypovolaemic shock: does it really reflect clinical reality? Resuscitation. 2013;84:309-13.

11 Mutschler M, Nienaber U, Brockamp T, Wafaisade A, Fabian T, Paffrath T et al. Renaissance of base deficit for the initial assessment of trauma patients: a base deficit-based classification for hypovolemic shock developed on data from 16,305 patients derived from the TraumaRegister DGU ${ }^{\circledR}$. Crit Care. 2013;17:R42.

12 Porter JM, Ivatury RR. In search of the optimal end points of resuscitation in trauma patients: a review. J Trauma. 1998;44:908-14.

13 Guerado E, Medina A, Mata M, Galvan JM, Bertrand ML. Protocols for massive blood transfusion: when and why, and potential complications. Eur J Trauma Emerg Surg. 2016;42:283-95.

14 Caputo N, Fraser R, Paliga A, Kanter M, Hosford K et al. Triage vital signs do not correlate with serum lactate or base deficit, and are less predictive of operative intervention in penetrating trauma patients: a prospective cohort study. Emerg Med J. 2013;30:546-50.

15 Dunne JR, Tracy JK, Scalea TM, Napolitano LM. Lactate and base deficit in trauma: does alcohol or drug use impair their predictive accuracy? J Trauma. 2005;58:959-66. 
16 Ibrahim I, Chor WP, Chue KM, Tan CS, Tan HL, Siddiqui FJ et al. Is arterial base deficit still a useful prognostic marker in trauma? A systematic review. Am J Emerg Med. 2016;34:626-35.

17 Lam SW, Lingsma HF, van Beeck EF, Leenen LP. Validation of a base deficit-based trauma prediction model and comparison with TRISS and ASCOT. Eur J Trauma Emerg Surg. 2016;42:627-33.

18 Raux M, Le Manach Y, Gauss T, Baumgarten R, Hamada S, Harrois A et al. Comparison of the Prognostic Significance of Initial Blood Lactate and Base Deficit in Trauma Patients. Anesthesiology. 2017;126:522-33.

19 Dunham MP, Sartorius B, Laing GL, Bruce JL, Clarke DL. A comparison of base deficit and vital signs in the early assessment of patients with penetrating trauma in a high burden setting. Injury. 2017;48:1972-77.

20 Herbert HK, Dechert TA, Wolfe L, Aboutanos MB, Malhotra AK, Ivatury RR et al. Lactate in trauma: a poor predictor of mortality in the setting of alcohol ingestion. Am Surg. 2011;77:1576-9.

21 Gustafson ML, Hollosi S, Chumbe JT, Samanta D, Modak A, Bethea A. The effect of ethanol on lactate and base deficit as predictors of morbidity and mortality in trauma. Am $\mathbf{J}$ Emerg Med. 2015;33:607-13.

22 Davis JW, Kaups KL. Base deficit in the elderly: a marker of severe injury and death. J Trauma. 1998;45:873-7.

23 Shakur H, Roberts I, Bautista R, Caballero J, Coats T, Dewan Y et al. Effects of tranexamic acid on death, vascular occlusive events, and blood transfusion in trauma patients 
with significant hemorrhage (CRASH-2): a randomised, placebo-controlled trial. Lancet. 2010;376:23-32.

24 Kutcher ME, Kornblith LZ, Narayan R, Curd V, Daley AT, Redick BJ, Nelson MF, Fiebig EW, Cohen MJ. A paradigm shift in trauma resuscitation: evaluation of evolving massive transfusion practices. JAMA Surg. 2013;148:834-40.

25 Hafeez W. Resuscitation. In: Cunningham S, Crain E, Gershel J, editors. Clinical Manual of Emergency Pediatrics. Cambridge: Cambridge University; 2010. pp. 1-29.

26 Fleming S, Thompson M, Stevens R, Heneghan C, Pluddemann A, Maconochie I et al. Normal ranges of heart rate and respiratory rate in children from birth to 18 years: a systematic review of observational studies. Lancet. 2011;377:1011-18.

27 Beloncle F, Meziani F, Lerolle N, Radermacher P, Asfar P. Does vasopressor therapy have an indication in hemorrhagic shock? Ann Intensive Care. 2013;3:13.

28 Gupta B, Garg N, Ramachandran R. Vasopressors: Do they have any role in hemorrhagic shock? J Anaesthesiol Clin Pharmacol. 2017;33:3-8.

29 Hylands M, Toma A, Beaudoin N, Frenette AJ, D'Aragon F, Belley-Côté É, Charbonney E et al. Early vasopressor use following traumatic injury: a systematic review. BMJ Open. 2017;7:e017559.

30 Mutschler M, Nienaber U, Münzberg M, Wölfl C, Schoechl H, Paffrath T et al. The Shock Index revisited - a fast guide to transfusion requirement? A retrospective analysis on 21,853 patients derived from the TraumaRegister DGU ${ }^{\circledR}$. Crit Care. 2013;17:R172.

31 Mofidi M, Hasani A, Kianmehr N. Determining the accuracy of base deficit in diagnosis of intra-abdominal injury in patients with blunt abdominal trauma. Am J Emerg Med. 2010;28:933-36. 
32 Aukema TS, Hietbrink F, Beenen LF, Leenen LP. Does thoracic injury impair the predictive value of base deficit in trauma patients? Injury. 2010; https://doi.org/10.1016/j.injury.2010.04.003

33 Bonanno FG. Hemorrhagic shock: The "physiology approach". J Emerg Trauma Shock. 2012;5:285-95.

34 Abou-Khalil B, Scalea TM, Trooskin SZ, Henry SM, Hitchcock R: Hemodynamic responses to shock in young trauma patients: need for invasive monitoring. Crit Care Med. 1994;22:633-9.

35 Guly HR, Bouamra O, Little R, Dark P, Coats T, Driscoll P et al. Testing the validity of the ATLS classification of hypovolaemic shock. Resuscitation. 2010;81:1142-7.

36 Brasel KJ, Guse C, Gentilello LM, Nirula R. Heart rate: is it truly a vital sign? J Trauma $2007 ; 62: 812-7$

37 Loftus TJ, Efron PA, Moldawer LL, Mohr AM. $\beta$-Blockade use for Traumatic Injuries and Immunomodulation: A Review of Proposed Mechanisms and Clinical Evidence. Shock. 2016;46:341-51.

38 Taniguchi T, Kurita A, Yamamoto K, Inaba H. Effects of carvedilol on mortality and inflammatory responses to severe hemorrhagic shock in rats. Shock. 2009;32:272-5.

39 Bonanno FG. Clinical pathology of the shock syndromes. J Emerg Trauma Shock. $2011 ; 4: 233-43$.

40 Cooke WH, Salinas J, Convertino VA, Ludwig DA, Hinds D, Duke JH et al. Heart rate variability and its association with mortality in prehospital trauma patients. J Trauma. 2006;60:363-70. 
41 Little RA, Kirkman E, Driscoll P, Hanson J, Mackway-Jones K. Preventable deaths after injury: why are the traditional 'vital' signs poor indicators of blood loss? J Accid Emerg Med. $1995 ; 12: 1-14$. 


\section{Figure legends}

Fig. 1. Study flowchart

The study flowchart illustrates that 684 trauma team activations occurred during the reported period. After excluding patients who were in cardiac arrest at scene or primary survey in an other institute, there were 542 patients left. 16 patients with detailed medical record could not be identified due to the lack of personal data. In 332 cases, there were either missing variables (HR/SBP/GCS/BD) or ISS, AIS or the accurate mechanism of injury was not recorded. A lack of 30-day follow up occurred in 38 cases. Ultimately, 156 patients were enrolled in the final analysis

Fig. 2. Distribution of patients (A) and mortality (B) among the shock severity classes based on VS and VS+BD

The difference in patient allocation mostly occurred in low-risk classes (I and II). Diagram A suggests that BD was not a key parameter in determining the severity class.

Diagram B shows that the vast majority of mortality is located in class IV

Fig. 3 ROC analysis of the individual variables

$\mathrm{HR}=$ heart rate, $\mathrm{SBP}=$ systolic blood pressure, $\mathrm{GCS}=$ Glasgow Coma Scale, $\mathrm{BD}=$ base deficit, AUROC=area under the receiver operating characteristic curve

ROC curves for the individual parameters. GCS has the largest AUCROC, showing the superiority of its predictive value over the other variable. A p-value $p<0.05$ was considered to be statistically significant

$* P<0.05$ 
A Szegedi Tudományegyetem, Traumatológiai Klinikal és Sebészeti Mütéttani Intézet ${ }^{2}$ közleménye

\title{
Figyelemfelhívás magyar polytrauma regiszter indítására - Egy tömegbaleset bemutatása*
}

\section{DR. CSONKA ENDRE ${ }^{1}$, DR. TUBOLY ESZTER ${ }^{2}$, DR. JÁVOR PÉTER ${ }^{1}$, DR. VARGA ENDRE ${ }^{1}$}

\begin{abstract}
ÖSSZEFOGLALÁS
Az utóbbi évtizedekben a sürgősségi traumatológia területén elért fejlődés és paradigmaváltások országos és nemzetközi regiszterek, valamint nagy elemszámú kohortok elemzésein alapultak. Cikkünk összesen 20 személy sérülésével járó tömegbaleset bemutatásán és az érintettek kezelése során nyert adatok elemzésén keresztül hívja fel a figyelmet a hazai trauma regiszter indításának szükségességére. A bemutatni kívánt tömegbaleset sérültjei közül kiválogattuk a súlyos sérülést szenvedett (Injury Severity Score $\geq 16$ ), helyszínen nem reszuszcitált, 16. életévet már betöltött személyeket. Ezen betegeknek a sérüléstől számított 6 . és 72 . órában levett rutin laborparaméterei kigyüjtésre kerültek. A paraméterek változásai, illetve egymással való kapcsolatuk Spearman-rangkorrelációk segítségével, SigmaStat 12.0 programban került elemzésre. 2017. október 3-án 8 súlyos sérült (átlag életkor: 34,85+-2,97; medián Injury Severity Score: 31.5 [27.5-37]) érkezett egyidőben a sürgősségi osztályunkra. Szignifikáns negatív kapcsolat igazolódott a 6 órás fehérvérsejtszám és a 72 órás kreatinin szint között ( $\mathrm{rs}=-0,949 ; \mathrm{p}=0,0167)$, valamint a 6 órás trombocitaszám és a 72 órás kreatinin szint között $(\mathrm{rs}=0,876 ; \mathrm{p}=0,0833)$. Hat és 72 órával a sérülés után mért rutin laborparamétereknek a két mintavétel között eltelt időintervallumban való változását vizsgálva a kreatinin, fehérvérsejt-és trombocitaszám mutattak szignifikáns változást. Súlyos sérülés után 6 és 72 órával mért kreatinin, fehérvérsejt-és trombocitaszámok kombinációban vizsgálva prediktív értékkel bírhatnak a kezelés kimenetelére. Új prognosztikus faktorok feltárásában egy esetleírás erősen korlátozott értékkel bír, véleményünk szerint eredményeink igazolásához és a hazai traumatológiai kutatás további fejlödéséhez egy magyar trauma regiszter elindítása lenne szükséges.
\end{abstract}

Kulcsszavak: polytrauma, tömegbaleset, regiszterek, szisztémás gyulladásos immunválasz szindróma, többszervi elégtelenség

E. Csonka, E. Tuboly, P. Jávor, E. Varga: Need for a national trauma registry-Presentation of a mass casualty

In the past decades, the development and paradigm shifts of trauma care were based on national and international registry and large cohort analyzes. The present study underlines the need for a Hungarian trauma registry through the presentation and analysis of a mass casualty with 20 injured people. Severely injured (Injury Severity Score $\geq 16$ ), adult ( $\geq 16$ years of age) patients who did not receive cardiopulmonal resuscitation on scene, were selected. 6-and 72hour post-injury routine labor parameters were collected retrospectively. The changes and associations of the parameter were analyzed with Spearman rank correlation tests in SigmaStat 12 software. On the $3^{\text {rd }}$ October 2017, 8 severely injured patients (mean age: 34,85+-2,97, median Injury Severity Score: 31.5 [27.5-37]) arrived to our Emergency Department at the same time. Our statistical analysis revealed a significant negative 
relationship between white blood cell count at 6 hours and blood creatinine level at 72 hours ( $\mathrm{rs}=-0.949 ; \mathrm{p}=0.0167)$ and between platelet count at 6 hours and creatinine at 72 hours (rs= 0,$876 ; p=0,0833$ ). The combination of these associations might have a predictive value for the outcome. Creatinine, white blood cell and platelet counts showed significant changes when their values at 6 and 72 hours were compared. The associations of creatinine levels, white blood cell and platelet counts measured at 6 and 72 hours post-injury might have a predictive value for the outcome in severe trauma. A case study has strong limitations in revealing new prognostic factors, therefore the establishment of a national trauma registry is required in order to validate our results and foster the development of Hungarian trauma research.

Keywords: polytrauma, mass casualty incidents, registries, systemic immune response syndrome, multiple organ failure

\section{BEVEZETÉS}

A súlyos sérültek (ISS $\geq 16$ ) vizsgálata és kezelése manapság is az egészségügyi ellátórendszerek kiemelten fontos feladata, hiszen zömében fiatalokat érint, és napjainkban is magas halálozással jár $(6,7)$. A súlyos trauma utáni első napot túlélők nagy számban érintettek posztoperatív szövődmények által és nagy kockázatúak a gyulladásos szervi diszfunkcióval járó kórállapotokra, szisztémás gyulladásos immunválasz szindrómára (SIRS), szepszisre és szervi elégtelenségekre nézve $(2,3,15)$. Ezen betegpopuláció terápiája rendkívül költséges és időigényes, átlagosan 2 hét intenzív osztályos (ITO) ellátással és elhúzódó rehabilitációs idővel jár (9). Habár a súlyos sérülések következményeinek társadalmi jelentősége vitathatatlan, az alkalmazott diagnosztikai és ellátási stratégiák még napjainkban is relatíve kevés tudományos evindenciával vannak alátámasztva. Az utóbbi évtizedekben, a sürgősségi traumatológia területén elért fejlödés és paradigmaváltások országos és nemzetközi regiszterek, valamint nagy elemszámú kohortok elemzésein alapultak $(13,14,16)$. Az egységes célból és módon, strukturáltan gyüjtött nagymennyiségü adat nyújtotta lehetőségeket felismerve a trauma regiszterek használata Nyugat-Európában egyre elterjedtebbé vált, és egy Egyesített Európai Trauma Regiszter koncepciója is megszületett (5). Tekintve, hogy régiónkban nem müködik trauma regiszter, rendkívül nagyszámú tudományos adat marad feldolgozatlanul. Egy polytrauma regiszter számos lehetőséget nyitna meg a hazai klinikusok számára, emellett a magyar traumatológiai ellátás magas színvonala azt is lehetővé tenné, hogy regiszterünk a jövőben egy európai szintü kollaboráció része lehessen.

Jelen cikkünk egy tömegbaleset bemutatásán és elemzésén keresztül hivatott felhívni a figyelmet hazai polytrauma regiszter szükségességére.

\section{ANYAG ÉS MÓDSZER}

Etikai engedély

A vizsgálat a Helsinki Egyezmény értelmében, a Szegedi Tudományegyetem Orvos Etikai Bizottságának engedélyével zajlott, az alábbi referenciaszámmal: 182/2019-SZTE.

\section{Esetkiválasztás, adatgyüjtés}

Jelen cikkünk olyan tömegbalesetet mutat be, mely során több személy is súlyos sérüléseket szenvedett (ISS $\geq 16$ ), azonban nem igényelt kardiopulmonális reszuszcitációt a helyszínen. A mindössze könnyü sérüléseket szerzett, valamint a 16. életévet be nem töltött 
sérültek kizárásra kerültek a vizsgálatból. Az SZTE Traumatológiai Klinikán kívül, egyéb intézményben első ellátásra került sérülteket szintén kizártuk elemzésünkböl. A betegek demográfiai adatai, ISS-e, 6 és 72 órával a baleset elszenvedése levett laborparaméterei (bázisdeficit/többlet, laktát, fehérvérsejtszám (WBC), trombocitaszám (PLT), kreatinin, bilirubin, AST, ALT, GGT), illetve mortalitásuk retrospektíven, Med-Solution rendszerből került kigyüjtésre, excel adattáblában.

\section{Statisztikai analízis}

A kinyert betegadatok statisztikai programban (Sigma Stat 12.0) kerültek elemzésre. A demográfiai adatokból deskriptív statisztika készült. A felvett laborparaméterek közötti lineáris kapcsolatok feltárására Spearman-korrelációt, a 6 és 72 órás laboreredmények összehasonlítására Wilcoxon-próbát használtunk.

\section{EREDMÉNYEK}

\section{Esetbemutatás}

2017. október 3-án egy 7-személyes mikrobusz a hatóságok elől nagy sebességgel menekülve letért az útról, felborult, majd többször átfordult. Az átalakított, utasülések nélküli 7 személyes jármüben a soförön kívül 19 személy utazott, köztük 3 gyerek. Az éjszakai órákra való tekintettel légi mentés nem volt elérhető. A földi mentőegységek 2 utast a jármü alá szorulva találtak. 1 utas a helyszínen az életét vesztette, 2 személyen kritikus állapotuk miatt helyszíni újraélesztést kellett kezdeni, 9 súlyos, 8 utas pedig könnyebb sérüléseket szenvedett. A 9 súlyos sérültből 2 még nem töltötte be a 16 . életévét, 1 személyt pedig elsőként nem a SZTE Traumatológiai Klinikára szállítottak a mentőegységek. Mindezek következtében 6 páciens került bevonásra analízisünkbe (1. ábra).

A helyszínen minden sérültnél perifériás vénabiztosítás, intravénás fájdalomcsillapítás, valamint krisztalloid infúzió bekötése történt, a nyaki gerinc és a sérült végtagok rögzítése mellett. Egy beteget intubálva, lélegeztetve szállítottak, a többi sérült arcmaszkon keresztül $100 \% \mathrm{O}_{2}$ szupplementációval került szállításra. Az átlagos szállítási idő az elhúzódó müszaki mentés miatt $111 \pm 28,61$ perc volt.

Az SZTE Traumatológiai Klinika betegei ATLS protokoll szerint kerültek ellátásra, klinikánk bázisa a magyarországi ATLS tanfolyamoknak, a legtöbb kollégánk és a társszakmák képviselői is nagy számban végezték el kurzusainkat. A sérültek triage beosztása döntötte el, melyik team látja el sérüléseit. Minden team egy traumatológusból (C, E doktor), egy aneszteziológusból (A, B, D doktor), egy traumás nővérből és egy aneszteziológus asszisztensből állt. A két kiskorú sérült stabilizálást és másodlagos állapotfelmérést követően a gyermekklinika Gyereksebészeti Osztályára került. Két felnőtt személy az ITO-ra, majd mütőbe került, egy non-responder sérültet pedig azonnal mütőbe szállítottak, ahol azonban életét vesztette. Minden beavatkozás a damage controll surgery szellemében történt, a töréseket elsődlegesen fixateur externe-nel rögzítettük. Egy sérült intrakraniális vérzését idegsebész látta el.

\section{A sérültek demográfiája és laborparaméterei}

2017. október 3-án 8 személy, 6 felnőtt és két kisgyermek érkezett egyszerre a SZTE Sürgősségi Betegellátó Osztályára többszörös törésekkel és tompa testüregi traumás sérülésekkel. A felnőttek átlag életkora $34.85 \pm 2.97$ év, medián ISS-ja 31.5 [27.5-37] volt. A tömegbaleset következményeként az intézetünkben kezelt sérültek közül egyetlen személy hunyt el (I. táblázat). 
Statisztikai vizsgálatok eredménye

A 6 órás WBC és a 72 órás kreatinin szint között ( $\mathrm{rs}=-0,949$; $\mathrm{p}=0,0167)$, valamint a 6 órás PLT és a 72 órás kreatinin szint között $(\mathrm{rs}=0,876 ; \mathrm{p}=0,0833)$ szignifikáns negatív korreláció igazolódott, ezen változásoknak lehet prediktív ereje kombinációban vizsgálva (2. ábra).

A 6 és 72 órával a sérülés után mért rutin laborparamétereknek a két mintavétel között eltelt időintervallumban való változását vizsgálva a PLT, WBC és kreatinin szintek mutattak szignifikáns változást (2. ábra).

\section{MEGBESZÉLÉS}

\section{Eredmények interpretálása}

Jelen cikkünk olyan tömegbalesetet mutat be, amelyben összesen 20 személy volt érintett. A súlyos sérültek kezelése során nyert adatok elemzésre kerültek. Vizsgálataink a sérülés után 6 és 72 órával levett rutin laborparaméterek változásainak dinamikáját, illetve egymással való kapcsolatát célozták meg a kezelés kimenetelére nézve potenciálisan prediktív értékkel bíró, új összefüggések kimutatása céljából.

A szakirodalomban jól dokumentált tény, hogy jelentős sérülések után a szöveti károsodás erős immunmodulátor hatású markerei szabadulnak fel, olyan hiperakut gyulladáskeltő citokinekkel mint a tumor nekrózis faktor- $\alpha$ (TNF- $\alpha$ ) és interleukin $1 \mathrm{~B}$, (IL1B). A citokin felszabadulás Toll-like receptorok (TLR) aktivációját okozza 1-2 órával később (10). Ezt a folyamatot a legjobban tetten érni közvetlenül a baleset után lehetne, egy helyszíni vérvétellel. A korai, szubakut citokinek (IL-6, IL-8, és IL-12, IL-18), valamint kemokinek és leukocita migrációs faktorok felszabadulása polimorfonukleáris sejt túlaktiválódást és reaktív oxigén gyökök (ROS) képződését okozza, melyek súlyosan befolyásolják a sérülés, illetve a kezelés kimenetelét (9). A fenti reakciók csúcsa a sérüléstől számított 4 és 12 óra között van $(1,11)$, így 6 órával a trauma után történő mintavétel ezen korai fázis vizsgálatára megfelelőnek tünik. Széles körben elfogadott, hogy a korai nagymértékü pro-inflammatorikus és a későbbi anti-inflammatorikus folyamatok képesek egymást facilitálni, destruktív immunológiai disszonanciát fenntartva (2). Ez nagyon súlyos következményekhez, SIRS-hez, többszervi elégtelenséghez (MOF) vezethet az első 72 órában (4). Mintavételeinket azért időzítettük 6 és 72 órával a sérülés után, hogy a laborparaméterek változását a fent leírt fázisokban vizsgálhassuk.

Vizsgálatunkban a 6 órás WBC és a 72 órás kreatinin szint között, valamint a 6 órás PLT és a 72 órás kreatinin szint között szignifikáns negatív kapcsolat igazolódott, ezen változásoknak lehet prediktív ereje kombinációban vizsgálva. Szemléltettük, hogy egyetlen baleset elemzése hipotézisek felállítására ugyan alkalmas mennyiségü, azonban egyértelmü következtetések levonásához kevés, illetve korlátozott értékü tudományos információt szolgáltathat. Tudományos hipotézisek validálásához nagy mennyiségü, egységes célból és módon, strukturáltan gyüjtött adatokra van szükség, melyre megoldást egy hazai trauma regiszter elindítása szolgálhatna. A trauma regiszterek tartalmazzák a sérültek demográfiai adatait, a sérülés körülményeit, prehospitális ellátást és transzportot, az első intézeti ellátás beavatkozásait, a sérülések anatómiai leírását, fiziológiai paramétereket, szövődményeket és a kimenetelt. Fontos és gyüjtendő adat a megelőző betegségek szerepeltetése, amelyek a kortól és a sérülések súlyosságától függetlenül is befolyásolják a kimenetelt. A jól dokumentált regiszter tartalmazza a laborértékeket is, amelyek elővetíthetnek rizikó faktorokat és másodlagos triggereket nem kívánatos események bekövetkeztéhez, ugyanakkor alkalmasak tudományos rizikó felmérésre, algoritmus alapú prediktív információkat adhatnak a kimenetelre. Fontos, hogy jó leírást adjon a helyi populációról, nemzeti regiszterként 
illeszkedve a nagyobb, összehasonlító regiszterekhez, és lehetőséget adjon a hasonlóságok és különbözőségek megfigyeléséhez.

\section{Következtetés}

A jelenlegi esetleírás és tanulmány a jól dokumentált, klinikailag és tudományosan átlátható adatbázisok fontosságát hangsúlyozza. Súlyos sérültek (ISS $\geq 16$ ) esetében, a kezelés 6. és 72. órájában mért laborparaméterek kombinációinak vizsgálata, ezen belül is a WBC, PLT és kreatinin értékek egymással való összefüggései prediktív értékkel bírhatnak a kezelés kimenetelére nézve. Új prognosztikus faktorok feltárásában egy esetleírás erősen korlátozott értékkel bír, így eredményeink validálásához, és a hazai traumatológiai kutatás további fejlödéséhez egy magyar trauma regiszter elindítása lenne szükséges.

\section{IRODALOM}

1. Bogner V., Keil L., Kanz K.G., Kirchhoff C., Leidel B.A., Mutschler W., Biberthaler P.: Very early posttraumatic serum alterations are significantly associated to initial massive RBC substitution, injury severity, multiple organ failure and adverse clinical outcome in multiple injured patients. Eur. J. Med. Res. 2009. 14. (7): 284-291.

2. Bone R. C.: Immunologic dissonance: a continuing evolution in our understanding of the systemic inflammatory response syndrome (SIRS) and the multiple organ dysfunction syndrome (MODS). Ann. Intern. Med. 1996. 125. (8): 680-687.

3. Chen G.Y. and Nuñez G.: Sterile inflammation: sensing and reacting to damage. Nat Rev Immunol. 2010. 10 (12): 826-837.

4. Dewar D., Moore F.A., Moore E.E., Balogh Zs.: Postinjury multiple organ failure. Injury. 2009. 40 (9): 912-918.

5. Edwards A., Di Bartolomeo S., Chieregato A., Coats T., Della Corte F., Giannoudis P., Gomes E., Groenborg H., Lefering R., Leppaniemi A., Lossius H.M., Ortenwal P., Roise O., Rusnak M., Sturms L., Smith M., Thomsen A.B., Willett K., Woodford M., Yates D., Lecky F.: A comparison of European Trauma Registries. The first report from the EuroTARN Group. Resuscitation. 2007. 75 (2): 286-297.

6. Evans J. A., van Wessem K. J. P., McDougall D., Lee K.A., Lyons T., Balogh Zs. J.: Epidemiology of traumatic deaths: comprehensive population-based assessment. World J. Surg. 2010.34 (1): 158-163.

7. Evans J. A., van Wessem K.J.P., McDougall D., Lee K.A., Lyons T., Balogh Zs.J.: Epidemiology of traumatic deaths: comprehensive population-based assessment. World J Surg. 2010. 34 (1): 158-163.

8. Fröhlich M., Driessen A., Böhmer A., Nienaber U., Igressa A., Probst C., Bouillon B., Maegele M., Mutschler M.: Is the shock index based classification of hypovolemic shock applicable in multiple injured patients with severe traumatic brain injury? An analysis of the TraumaRegister DGU ${ }^{\circledR}$. Scand J Trauma Resusc Emerg Med. 2016. 24 (1): 148.

9. Hemmila M.R., Cain-Nielsen A.H., Wahl W.L., Vander Kolk W.E., Jakubus J.L., Mikhail J.N., Birkmeyer N.J.: Regional collaborative quality improvement for trauma reduces complications and costs. J Trauma Acute Care Surg. 2015.78 (1): 78-85.

10. Hietbrink F., Koenderman L., Rijkers G., Leenenet L.: Trauma: the role of the innate immune system. World J Emerg Surg. 2006. 1:15.

11. Keel M. and Trentz O.: Pathophysiology of polytrauma. Injury. 2005. 36 (6): 691-709. 
12. Kernacki K.A., Goebel D.J., Poosch M.S., Hazlett L.D.: Early cytokine and chemokine gene expression during Pseudomonas aeruginosa corneal infection in mice. Infect Immun. 1998. 66 (1): 376-379.

13. Mutschler M., Fau-Nienaber U., Brockamp T., Wafaisade A., Fabian T., Paffrath T., Bouillon B., Maegele M., TraumaRegister DGU: Renaissance of base deficit for the initial assessment of trauma patients: a base deficit-based classification for hypovolemic shock developed on data from 16,305 patients derived from the TraumaRegister DGU ${ }^{\circledR}$. Crit Care. 2013. 17 (2): R42.

14. Mutschler M., Paffrath T., Wölfl C., Probst C., Nienaber U., Schipper I. B., Bouillon B., Maegele M.: The ATLS(®) classification of hypovolaemic shock: a well established teaching tool on the edge? Injury. 2014. 45. (Suppl. 3): S35-38.

15. Oka Y., Murata A., Nishijima J., Yasuda T., Hiraoka N., Ohmachi Y., Kitagawa K., Yasuda T., Toda H., Tanaka N., et al.: Circulating interleukin 6 as a useful marker for predicting postoperative complications. Cytokine. 1992. 4 (4): 298-304.

16. Roberts I., Shakur H., Coats T., Hunt B., Balogun E., Barnetson L., Cook L., Kawahara T., Perel P., Prieto-Merino D., Ramos M., Cairns J., Guerriero C.: The CRASH-2 trial: a randomised controlled trial and economic evaluation of the effects of tranexamic acid on death, vascular occlusive events and transfusion requirement in bleeding trauma patients. Health Technol Assess. 2013. 17 (10): 1-79.

\section{Dr. Csonka Endre}

Szegedi Tudományegyetem, Traumatológiai Klinika 
TÁBLÁZAT, ÁBRÁK

\begin{tabular}{|c|c|c|}
\hline Demográfia és mortalitás & & \\
\hline Életkor átlag \pm SD & \multicolumn{2}{|c|}{$34.85 \pm 2.97$} \\
\hline Férfi nem \% & \multicolumn{2}{|c|}{83.44} \\
\hline ISS & \multicolumn{2}{|c|}{$36.83 \pm 14.93$} \\
\hline ISS medián [IQR] & \multicolumn{2}{|c|}{$31.5[27.5-37]$} \\
\hline Mortalitás (\%) & \multicolumn{2}{|c|}{16.66} \\
\hline Laborparaméterek & $\begin{array}{c}6 \text { órával a sérülés } \\
\text { után }\end{array}$ & $\begin{array}{c}72 \text { órával a sérülés } \\
\text { után }\end{array}$ \\
\hline Bázisfelesleg/többlet (mmol/l) & $-2.13 \pm 2.90$ & $0.47 \pm 3.09$ \\
\hline Laktát (mmol/l) & $3.23 \pm 1.50$ & $1.27 \pm 0.67$ \\
\hline WBC (G/L) & $18.69 \pm 6.22$ & $7.56 \pm 0.91^{*}$ \\
\hline $\operatorname{PLT}(G / L)$ & $251.83 \pm 80.99$ & $126.00 \pm 19.15^{*}$ \\
\hline Kreatinin ( $\mu \mathrm{mol} / \mathrm{l})$ & $88.00 \pm 13.58$ & $63.5 \pm 5.97^{*}$ \\
\hline Bilirubin $(\mu \mathrm{mol} / \mathrm{l})$ & $10.34 \pm 1.32$ & $24.73 \pm 17.51$ \\
\hline AST (U/I) & $79.4 \pm 20.05$ & $70.33 \pm 26.57$ \\
\hline $\operatorname{ALT}(\mathrm{U} / \mathrm{I})$ & $64.4 \pm 22.26$ & $51.33 \pm 34.36$ \\
\hline GGT (U/I) & $29.6 \pm 18.42$ & $19.67 \pm 14.22$ \\
\hline
\end{tabular}

$* \mathrm{P}>0.05$

\section{I. táblázat}

A sérültek demográfiai adatai és laborparaméterei

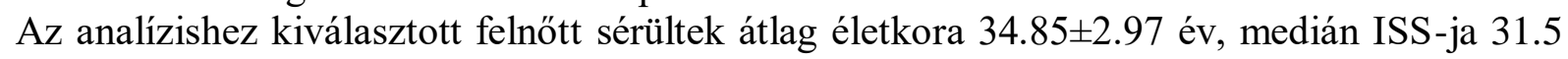

[27.5-37] volt. Egyetlen haláleset történt, 16.66\%-os mortalitási rátát eredményezve. 


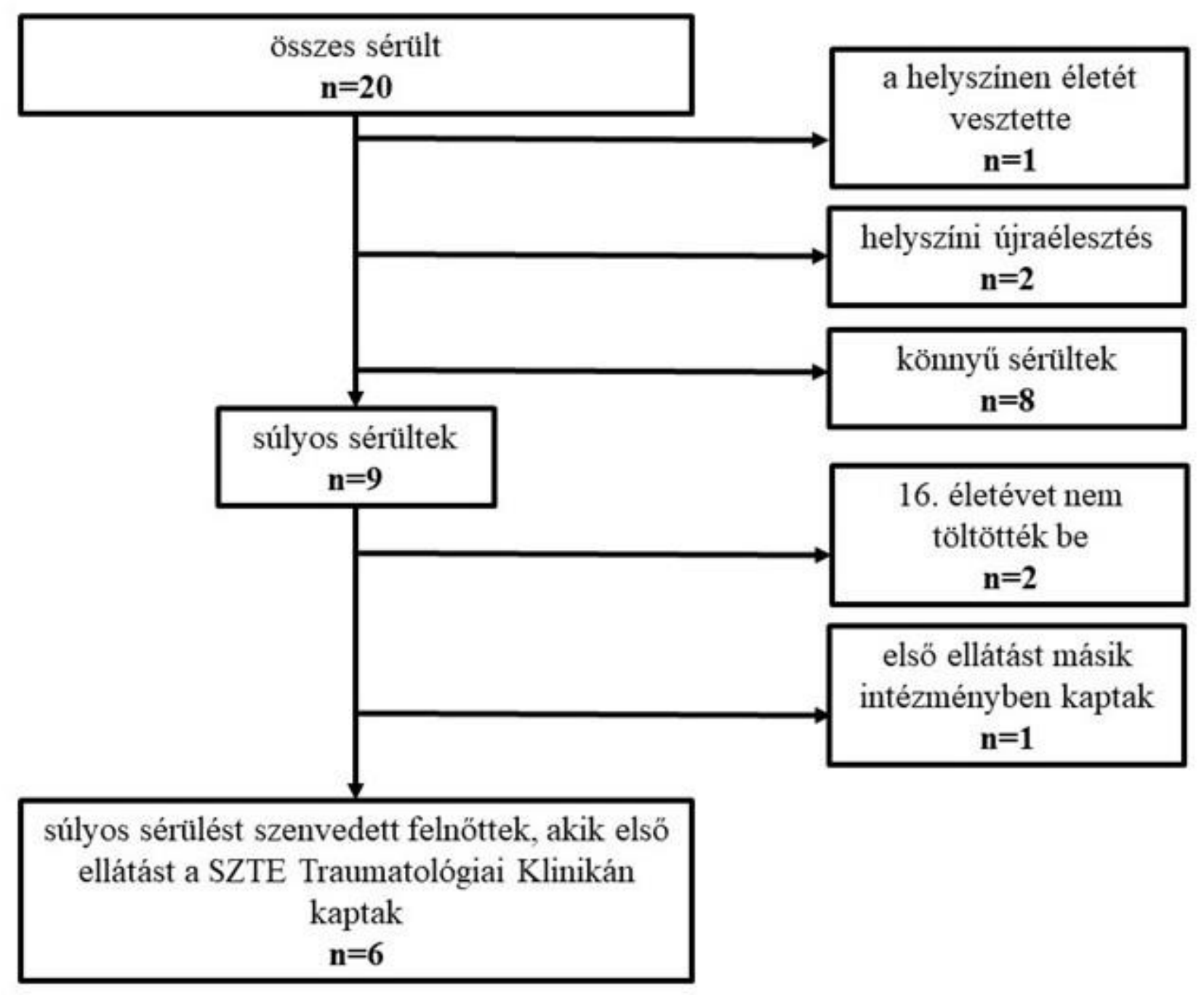

\section{1. ábra}

Betegek beválogatása az analízisbe

A bemutatni kívánt tömegbalesetben 20 személy sérült. 1 ember a helyszínen életét vesztette. 2 személyen a mentőegységek a helyszínen újraélesztést kezdtek, 8-an pedig csak könnyebb sérüléseket (ISS <16) szenvedtek, így kizárásra kerültek az analízisből. A fennmaradó 9 súlyos sérült (ISS $\geq 16$ ) közül 2 -en még nem töltötték be 16 . életévüket, 1 személyt pedig a mentők egy másik vidéki kórházba szállítottak első ellátásra. Végül 6 személy adatai kerültek elemzésre. 
A

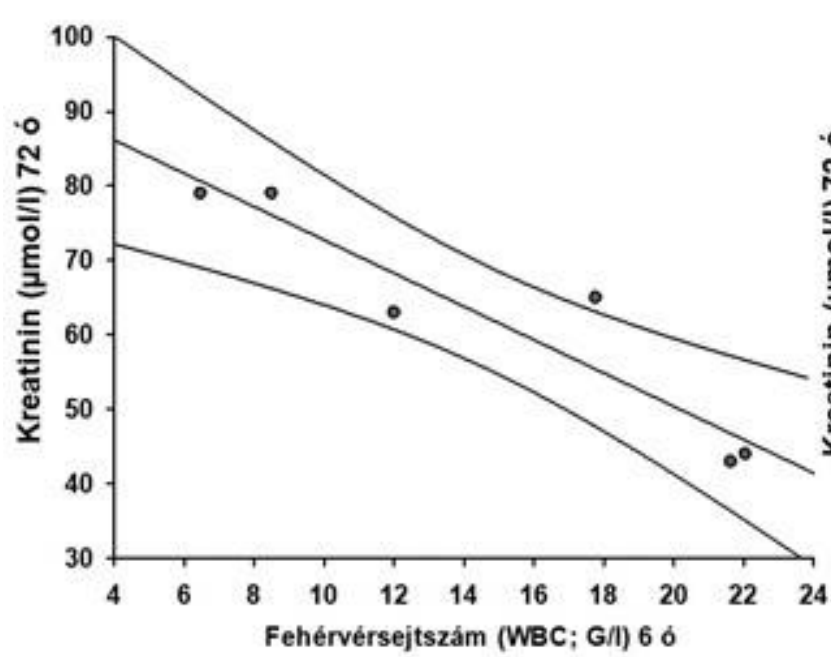

B

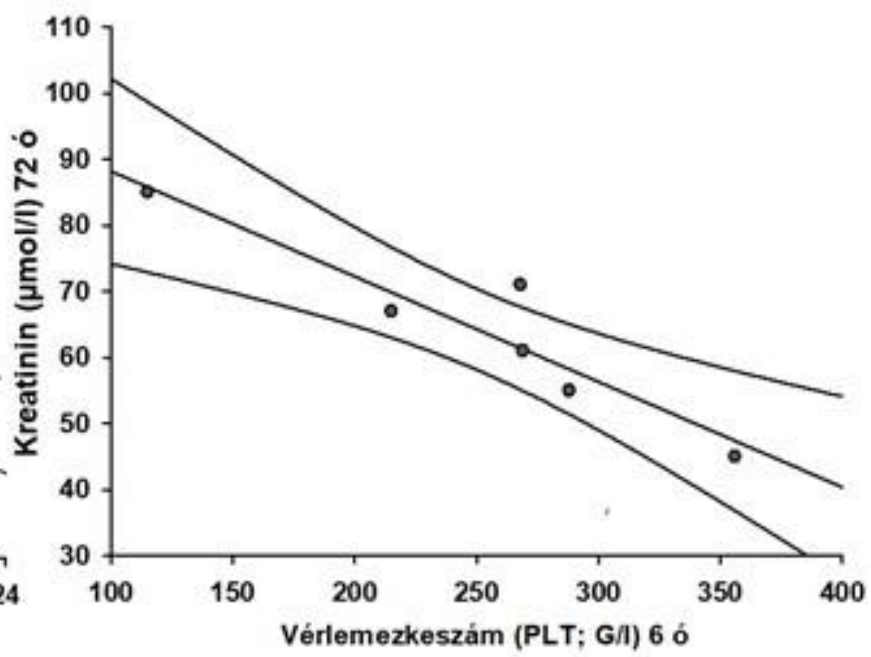

\section{2. ábra}

Szignifikáns kapcsolatok a 6 és 72 órás laborparaméterek között

A 6 órás WBC és a 72 órás kreatinin szint között $(r s=-0,949 ; p=0,0167)(\mathbf{2 A})$, valamint a 6 órás PLT és a 72 órás kreatinin szint között ( $\mathrm{rs}=0,876 ; \mathrm{p}=0,0833)$ (2B) szignifikáns negatív kapcsolat igazolódott. 